Review

\title{
Peripheral blood biomarkers in multiple sclerosis
}

\section{Antonella D'Ambrosio a, Simona Pontecorvo ${ }^{\mathrm{b}}$, Tania Colasanti ${ }^{\mathrm{a}}$, Silvia Zamboni ${ }^{\mathrm{a}}$, Ada Francia ${ }^{\mathrm{b}}$, Paola Margutti ${ }^{\mathrm{a}, *}$}

a Department of Cell Biology and Neurosciences, Istituto Superiore di Sanità, Rome, Italy

b Multiple Sclerosis Center of Department of Neurology and Psychiatry of "Sapienza" University of Rome, Italy

\section{A R T I C L E I N F O}

\section{Article history:}

Received 6 July 2015

Accepted 23 July 2015

Available online $\mathrm{xxxx}$

\section{Keywords:}

Multiple sclerosis

Biomarkers

Autoimmune disease

Therapy

\begin{abstract}
A B S T R A C T
Multiple sclerosis is the most common autoimmune disorder affecting the central nervous system. The heterogeneity of pathophysiological processes in MS contributes to the highly variable course of the disease and unpredictable response to therapies. The major focus of the research on MS is the identification of biomarkers in biological fluids, such as cerebrospinal fluid or blood, to guide patient management reliably. Because of the difficulties in obtaining spinal fluid samples and the necessity for lumbar puncture to make a diagnosis has reduced, the research of blood-based biomarkers may provide increasingly important tools for clinical practice. However, currently there are no clearly established MS blood-based biomarkers. The availability of reliable biomarkers could radically alter the management of MS at critical phases of the disease spectrum, allowing for intervention strategies that may prevent evolution to long-term neurological disability. This article provides an overview of this research field and focuses on recent advances in blood-based biomarker research.
\end{abstract}

c 2015 Published by Elsevier B.V.

\section{Contents}

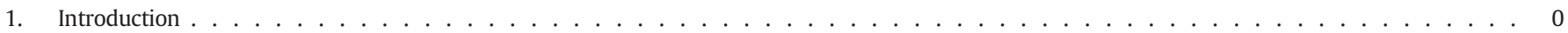

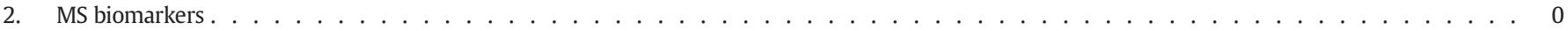

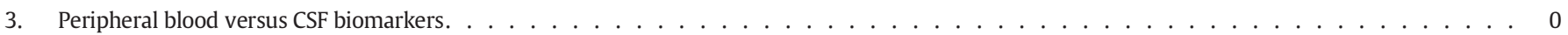

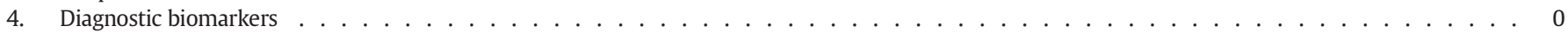

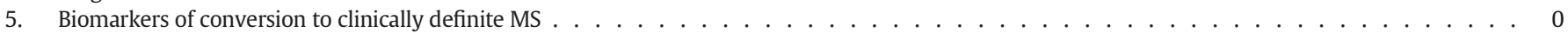

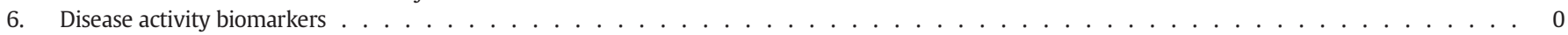

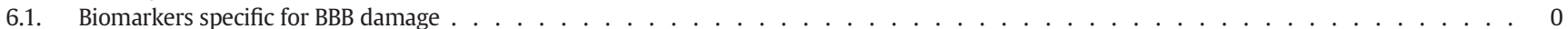

6.2. Biomarkers associated with BBB damage . . . . . . . . . . . . . . . . . . . . . . . . . . . . . . . . . . . . . . . . . . 0

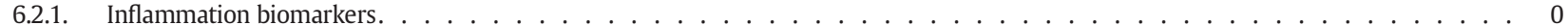

6.2.2. Microvesicles . . . . . . . . . . . . . . . . . . . . . . . . . 0

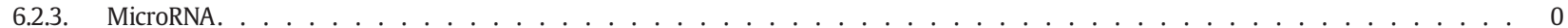

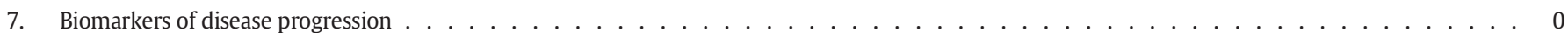

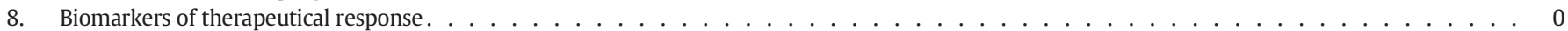

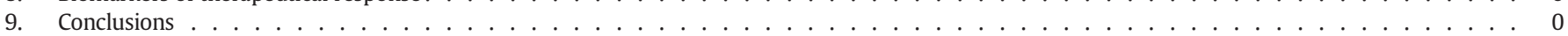

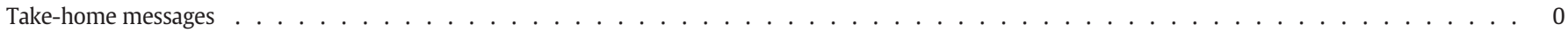

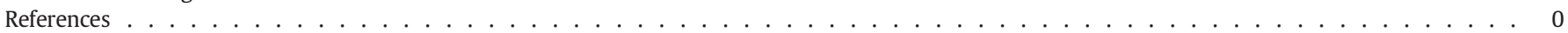

\section{Introduction}

Multiple sclerosis (MS) is an immune-mediated, inflammatory demyelinating and neurodegenerative disease of the central nervous

\footnotetext{
* Corresponding author at: Istituto Superiore di Sanità, Cell Biology and Neuroscience Department, Viale Regina Elena, 299-00161 Rome, Italy. Tel.: + 3949902424

E-mail address: paola.margutti@iss.it (P. Margutti).
}

system (CNS). MS has a heterogeneous clinical presentation and course, reflecting complexity in its pathophysiology, and is classified into three main types of clinical courses: relapsing-remitting (RRMS), primary progressive (PPMS), and secondary progressive (SPMS) [1]. In most cases, RRMS turns at one point into a SPMS form, characterized by the irreversibility of the deficits due to progressive neurodegeneration. Meanwhile, PPMS is characterized by a gradual progression of disability from the onset of the disease [1]. Although the etiology of MS is 
unknown, evidence suggests that the disease may result from a complex interaction between the environmental factors, the genetic background that defines individual susceptibility, and the immunological and physiological settings of the individual [2]. The pathological hallmarks of MS are inflammation, demyelination, remyelination, neurodegeneration and glial scar formation, which occur either focally or diffusely throughout the white and grey matter in the brain and spinal cord [3]. These pathological features are present in both RRMS and SPMS, as well as in PPMS, although they vary over time both quantitatively and qualitatively between these three forms of MS and among individuals with the same form of the disease, thus contributing to the heterogeneity in phenotypic expression of the disease and response to therapies $[4,5]$. As supported by experimental evidence, mainly derived from its principal model experimental allergic encephalomyelitis (EAE), MS is generally considered a predominantly T cell-mediated autoimmune disease. Indeed, inflammatory lymphocytes transmigrate into the CNS and initiate tissue damage and neurological impairment [6]. Even though myelin specific Th1 and Th17 $\mathrm{CD}^{+}{ }^{+} \mathrm{T}$ cells are involved in the disease, also other cell types like $\mathrm{CD}^{+} \mathrm{T}$ cells, B cells, macrophages and natural killer (NK) cells contribute to the pathogenesis of MS [7-9]. It is likely that inflammatory responses are the key mediators of early disease in most cases and, over time, there is incremental neurodegeneration correlating with progressive disability. However, current evidence indicates that in all forms and stages of the disease, inflammation seems to drive demyelination and neurodegeneration, and in the progressive stage, in contrast to early stage with $\mathrm{BBB}$ compromise, inflammation is partially trapped within the CNS behind the BBB, which makes the current anti-inflammatory treatment to become ineffective [4]. Along these lines, mechanisms of the pathophysiology of MS involve mainly three physiological compartments: 1) the peripheral blood, in which immune processes mainly take place; 2 ) the blood brain barrier (BBB), which breaks down to a point so that immune cells can pass into the CNS; and 3) the CNS, in which lesions mark acute sites of inflammation and neural damage, leading to the phenotypic displayed symptoms of disability. In each of these compartments, changes in gene expression of a certain set of proteins and cell types are characteristic hallmarks of MS. The clinical disability of MS patients is evaluated using the Expanded Disability Status Scale (EDSS) [10], while the disease activity is evaluated using magnetic resonance imaging (MRI) with gadolinium (Gd)-enhancing lesions, providing the most objective and sensitive tool for assessing the progression and activity of the disease in MS patients.

\section{MS biomarkers}

Biomarkers are measurable indicators of normal biological and pathogenic processes, or pharmacological responses to a therapeutic intervention. A good biomarker should be precise and reliable, able to distinguish between MS disease and control, can detect inflammatory activity, as well as the degree of neurodegeneration and demyelination/remyelination, in order to get a more accurate picture of the disease status [11]. Since for many years intensive efforts have been directed toward the identification of biomarkers in body fluids (CSF or blood) associated with various aspects of MS on different levels of the organizational hierarchy of the human body (e.g. DNA, RNA, proteins, cells) [12], the application of more advanced screening technologies has opened up new categories of biomarkers, including gene expression and autoantibody arrays, microRNAs (miRNAs), and circulating microvesicles (MVs). However, despite the large sum of studies provided in a long list of candidate biomarkers, most of them have not been validated, and therefore they are not clinically useful at present. Moreover, the lack of validation is a common problem with biomarkers of complex diseases such as MS, reflecting a bias in statistical analysis or a lack of available data, but it may also indicate difficulties in performing clinical validation studies [13].

\section{Peripheral blood versus CSF biomarkers}

In MS, most studies search for biomarkers within the CSF with the view that this is more likely to reflect CNS disease. However, blood-based biomarkers are of great clinical value, because of the ease with which blood can be obtained in a minimally invasive manner. Blood biomarkers may exist in MS if there is a systemic component of the disease, or if peripheral changes mimic central disease [14]. The biologic events associated with a focal active inflammatory cerebral lesion may not be readily detectable in the peripheral blood. Furthermore, immune abnormalities in the peripheral blood in MS patients may also lack specificity because they may be altered by systemic events, such as viral infections. Despite these limitations, peripheral blood biomarkers can give important information regarding immune triggers of MS, as well as therapeutic efficacy of drugs administered [15]. Additionally, blood has two properties that make it attractive for the search for biomarkers: 1 ) it is more easily accessible than other body tissues; and 2) the perfusion of blood through different organs and tissues can result in the addition of new proteins, or modification of existing proteins, which may vary according to specific physiological or pathological conditions [16]. Thus, the blood can carry molecules derived from other tissues, reflecting the biological status of the body [17]. Peripheral biomarkers in MS can be categorized into five groups: diagnostic, associated with the conversion to clinically definite MS (CDMS), disease activity, progression and treatment-response (Table 1).

\section{Diagnostic biomarkers}

Diagnostic biomarkers can be used to distinguish patients who have MS from patients with other neurological or autoimmune disorders, or from healthy individuals. Indeed, white-matter lesions typical of MS can be seen in many other neuroinflammatory conditions, such as neurosarcoidosis, neuroborreliosis, Sjögren Syndrome, and systemic lupus erythematosus. For this reason, a set of diagnostic criteria (the revised McDonald's criteria [18,19]) that incorporates clinical, radiologic, and laboratory findings is used to establish a definitive diagnosis of MS. The only validated biomarker for MS diagnosis in clinical practice is the detection of oligoclonal IgG bands (OCGB) in the CSF. Thus, MRI of the brain and spine together with OCGB formation in CSF reflects the inflammatory and demyelinating nature of the disease and is an important tool in the diagnosis of MS $[18,20]$. Autoantibodies have been documented to be valuable diagnostic biomarkers for several autoimmune diseases. Furthermore, serum antibodies against specific antigens have been established also in several neuro-immunological diseases, such as myasthenia (antibodies against acetylcholine receptor) and paraneoplastic disorders (e.g. anti-Hu, anti-Yo) [21,22]. The importance of autoantibodies as diagnostic biomarkers has been emphasized following the discovery of a serum pathogenic specific antibody targeting the principal water channel of astrocyte aquaporin-4 (termed NMO-IgG or AQP4-Ab), distinguishing neuromyelitis optica (NMO), also known as Devic's disease, from MS [23,24]. Initially, many studies investigated the autoantibodies targeting myelin proteins as biomarkers of the disease, well established in EAE, where anti-myelin antibodies induce CNS demyelination [25]. However, the detection of serum antibodies to myelin basic protein (MBP), myelin-associated glycoprotein, and proteolipid protein has resulted in conflicting data, which in all cases lacked specificity, sensitivity, and reproducibility [26-28]. Among these myelin autoantigens, myelin oligodendrocyte glycoprotein (MOG) has emerged as a promising autoantigen, especially in autoimmune pediatric demyelination in both acute disseminated encephalomyelitis and MS [29]. Meanwhile, the role of MOG antibodies in adult MS patients is still speculative, thus more research is needed to clarify if MOG antibodies can be used for prognosis or classification of 
Table 1

Potential peripheral blood biomarkers in MS.

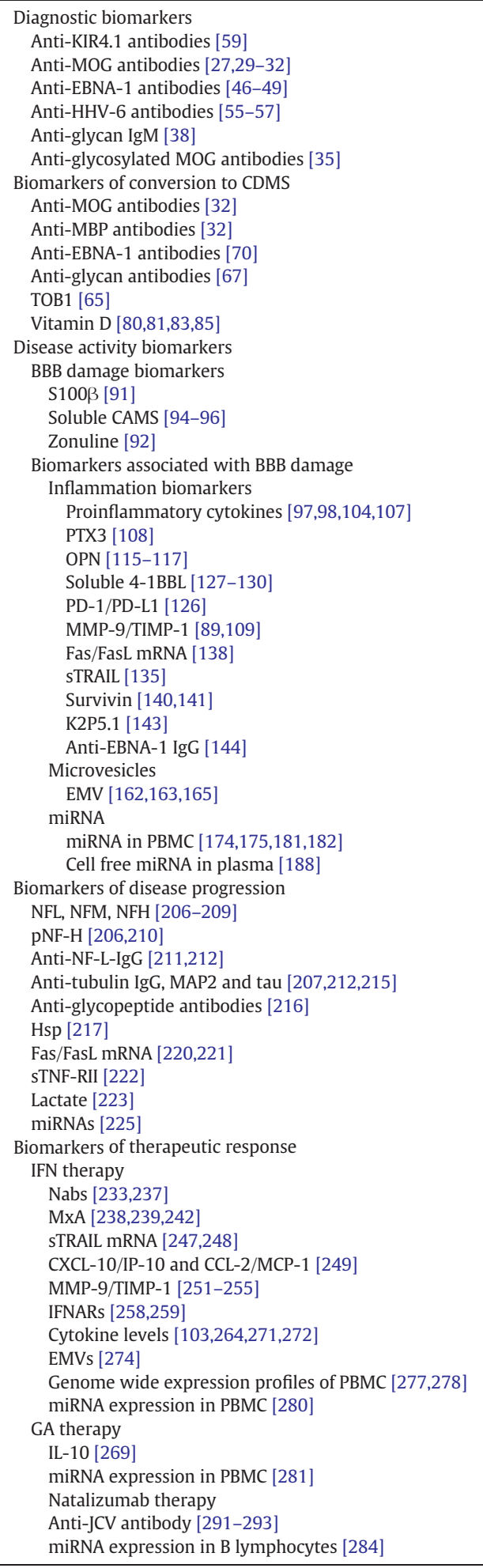

adult MS patients [27]. The discrepancy in results about MOG antibody detection is probably due to the use of different detection methods (ELISA, western blot and immunohistochemistry) and different antigens (native MOG, recombinant MOG or synthetic peptides) [30-32]. Growing evidences indicate that post-translational modifications (i.e. acetylation, lipidation, citrullination, glycosylation), either native or aberrant, may play a fundamental role for specific autoantibody recognition in autoimmune diseases [33,34]. Thus, synthetic peptides can be specifically modified to mimic neo-antigens and to selectively detect autoantibodies as disease biomarkers. A "chemical reverse approach" to select synthetic peptides has been established, bearing specific post-translational modifications, able to fish out autoantibodies from the patients' body fluids. This approach is successfully applied for the development of specific in vitro diagnostic/prognostic assays of autoimmune diseases [34-37]. In line with these observations, an increase of antibody reactivity against glycans composed of $\alpha$-glucose disaccharide anti-Glc $(\alpha 1,4) \operatorname{Glc}(\alpha) \operatorname{IgM}($ anti-G $\alpha 4 \mathrm{G} \alpha \operatorname{IgM})$ was shown in the serum of RRMS patients but not in the serum of patients with other neurological diseases [38]. The biological importance of anti$\mathrm{G} \alpha 4 \mathrm{G} \alpha$ IgM was further confirmed in another study, suggesting that such antibodies would be considered as a diagnostic biomarker for its role in distinguishing RRMS patients from those with other neurological diseases [39]. Alpha-glucose-based polysaccharides are found in the cell wall of several pathogenic fungi [40] and bacteria [41], suggesting that IgM antibodies could arise through the mechanism of molecular mimicry. The biological basis of a humoral response to $\alpha$-glucose antigen is still unclear, but it is of interest that this particular carbohydrate ( $\alpha$-glucose) is found within the type IV collagen matrix of the BBB. It has been hypothesized that in MS patients these carbohydrate antigens may be released during an inflammatory response at the BBB [42]. Furthermore, the humoral response to post-translationally modified components of myelin in serum patients was analyzed. In particular, it was found that only the glycosylated analogue of the MOG immunedominant epitope [Asn31(Glc)] human MOG(30-50) was recognized by antibodies in MS patients, but not in healthy subjects [35]. There is considerable evidence that Epstein-Barr virus (EBV) infection is a strong risk factor for the development of MS [43]. Most importantly, MS risk is extremely low in individuals who are EBV negative, but it increases several folds following EBV infection; thus, evidence of EBV infection may have relevance for MS diagnosis [44]. The presence of antibodies to EBV is not considered to be diagnostically relevant, because a number of studies have shown the presence of antibodies against EBV in $99 \%$ of MS patients, but also in $90 \%$ of the general population [45]. Current investigations are focused on determining whether MS patients have antibodies to unique determinants of EBV. More recently, serum antibody titer against EBV nuclear antigen-1(EBNA-1) has been suggested to be associated with disease activity and presented as a possible biomarker in MS [46]. Several studies have explored the antibody response to specific segments of the EBNA-1 antigen $[47,48]$. Sera from MS onset pediatric patients recognized a broader range of distinct epitopes within EBNA-1, particularly three unique regions [49]. Antibodies specific to one of these epitopes (EADYFEYHQE, amino acids 411-420) were associated with the highest MS risk in an adult study, in which the combination between HLA-DRB $1 * 15$ and antibody reactivity to epitope 411-420 was associated with a 24-fold increased risk for MS [47]. Human herpes virus type 6 (HHV-6), like EBV, could be an important causative factor in MS [50]. HHV-6 virtually infects all children by the age of 2 years [51], so it has not been possible to compare the MS risk for infected versus non-infected individuals. Evidence for HHV-6 involvement in the pathogenesis of MS is based on pathological data showing the presence of the virus in MS postmortem lesions $[52,53]$ and its neurotropic nature [54]. Recent studies have demonstrated increased titers of IgM and IgG antibodies specific to a variant of HHV-6 present in both serum and CSF of patients in the earliest phases of MS [55-57]. Conversely, a treatment trial with anti-viral agents effective against HHV-6 had no beneficial effect in patients with MS [58], suggesting that different viruses may be responsible for the same clinical entity across the population of MS patients. A very recent discovery is the increased humoral immune response against KIR4.1, a rectifying potassium channel expressed by astrocytes and oligodendrocytes found in different cohorts of MS patients. In particular, serum levels of antibodies to KIR4.1 were higher in MS (46.9\%) than in other neurologic diseases and healthy subjects [59]. Based on these data, it has been concluded that KIR4.1 is a CNS-specific target of the 
autoantibody response in a subgroup of patients with MS [59]. Furthermore, the injection of the specific IgG for KIR4.1 (derived from MS sera) into the cisterna magna of mice caused pathological changes like complement deposition and loss of KIR4.1 antigen, suggesting a pathogenic role for this kind of antibodies [59]. However, as regarding MOG, it remains to be seen if the immune response against KIR4.1 will be useful as a biomarker for diagnosis.

\section{Biomarkers of conversion to clinically definite MS}

Clinically isolated syndrome (CIS) is a term that describes a first clinical episode with features suggestive of MS. It usually occurs in the young. Approximately, one-third of CIS patients progresses to CDMS within one year after diagnosis, and approximately half of them do so after 2 years [60]. Up to now, lesion load in the initial MRI and the presence of OCGB in the CSF of CIS patients have been the best validated prognostic paraclinical measures [61-63]. Overall, an early MRI can predict with high certainty whether a patient will develop MS, but cannot accurately determine when this will occur. On the other hand, the utility and predictive value of anti-myelin antibodies remain controversial [32, 64]. CIS patients represent a unique population for the study of early molecular events that lead to demyelination and axonal degeneration. In this vein, a microarray experiment was conducted to study gene expression in naïve $\mathrm{CD} 4^{+} \mathrm{T}$ cells in CIS patients at the time of diagnosis and after one year, in order to identify genes correlating with conversion to MS [65]. This study revealed a molecular signature that identified a group of CIS patients with high risk of MS conversion with high accuracy. In particular, a gene encoding a transcription factor critical for repression of T-cell proliferation, TOB1, was found to be significantly down-regulated in the group of CIS patients who rapidly converted to MS [65]. These results indicate that CIS patients with high risk of MS conversion have impaired regulation of $\mathrm{T}$ cell quiescence, possibly resulting in earlier activation of pathogenic $\mathrm{CD}^{+} \mathrm{T}$ cells [65]. In addition, genetic analysis in an independent cohort of MS patients identified a genetic association between specific TOB1 polymorphisms and clinical progression to mild or severe MS phenotypes [65]. Further studies will be needed to determine the predictive value of TOB1 expression as a biomarker for CIS conversion to MS. Recently, it has been shown that measuring anti- $\alpha$-glucose IgM levels could provide not only a possible diagnostic biomarker for MS, as reported below, but also an independent and more specific predictive factor for early conversion to CDMS. In particular, higher serum levels of a panel of anti-G $\alpha 4 \mathrm{G} \alpha$ and $\alpha$-glucose glycan seem to assist in the prediction of CIS patients who are prone to an imminent relapse, within 24 months [66]. Thus, a classification rule named gMS-Classifier2, an algorithm based on the combination of polyclonal serum IgM antibody levels against P63 (a polymer based on $\operatorname{Glc}(\alpha 1-3) \operatorname{Glc}(\alpha)$ and $\operatorname{Glc}(\alpha 1-6) \operatorname{Glc}(\alpha)$ ) and age was developed after an exploration analysis of clinical data and antiglycan antibody levels in samples collected in the "Betaferon ${ }^{\circledR}$ in Newly Emerging MS" [67]. It was shown that gMS-Classifier2 is an independent predictor for the conversion of CIS patients to CDMS in the first year of the disease course and therefore could be of clinical relevance to determine which patients are at higher risk, particularly in cases in which OCB is not available [67]. Several studies have shown elevated frequencies of anti-MOG levels in MS patients, as reported in the previous section $[32,68,69]$. Although not universally confirmed, it has been shown that the presence of serum anti-MOG and -MBP antibodies in CIS patients significantly increased the conversion rate of CIS to RRMS [32]. Furthermore, elevated immune responses toward EBNA1 are selectively increased in CIS patients and suggest that EBNA1-specific IgG titers could be used as a prognostic marker for disease conversion and disability progression [70]. Epidemiological studies have linked vitamin D status with autoimmune disease susceptibility and severity [71-74]. Experimental evidence suggests that high levels of vitamin D, a potent immunomodulator, may decrease the risk of MS [75-77], suggesting a protective role for vitamin D in MS development [78]. Several studies have shown that administration of the biologically active hormone 1,25-dihydroxyvitamin D prevents EAE onset and progression in mice $[79,80]$. On the contrary, in some studies an inverse correlation between vitamin D status and MS activity was reported [81-83]. However, recently, a robust association between depressed vitamin D levels and the development of more severe measures of MS was shown, including time to diagnosis, new lesions, volume of lesions, and brain volume [84]. These results provide evidence that low serum 25(OH)D (25-hydroxyvitamin D) levels are an important risk factor for the conversion from CIS to MS and for long-term progression, suggesting that serum 25(OH)D level may be a prognostic biomarker for CDMS in CIS patients $[83,85,86]$.

\section{Disease activity biomarkers}

RRMS is defined by immune-mediated inflammatory demyelinating attacks, causing lesions associated with a breakdown of the BBB and the presence of blood-derived lymphocytes and monocytes in the CNS. Resolution of the inflammation, restoration of the conduction block and re-myelination contribute to the clinical recovery [87]. The current gold standard as a marker of active disease is detection of Gd enhancement of white-matter lesions on brain MRI. On the other hand, brain MRI is not accurate for the assessment of subcortical grey demyelination and for a measure of axonal and neuronal loss and inflammatory whitematter demyelination. Additionally, spinal MRI is less sensitive than brain MRI in detecting lesions [20]. Furthermore, several factors may limit the ability to use the presence of Gd enhancement as the ultimate biomarker of BBB disruption, such as the dose of administered Gd, the time elapsed between Gd injection and image acquisition, and the severity of BBB disruption $[20,88]$. Ongoing research has led to find out several disease activity biomarkers which can be divided into two subsets: biomarkers specific for BBB damage and biomarkers associated with BBB damage. In particular, the section of biomarkers associated with BBB damage includes: inflammation biomarkers, MVs and miRNA.

\subsection{Biomarkers specific for BBB damage}

The BBB is present in a complex cellular system in which tight junctions between endothelial cells play a crucial role. Cells that compose the BBB in association with the basal laminae include endothelial cells, pericytes, perivascular microglia and astrocyte processes. In particular, astrocyte endfeet surrounding brain blood vessels contribute to induction and maintenance of the endothelial barrier [89]. Several biomarkers have been studied for their ability to reflect BBB disruption and brain damage in MS, but only a few studies report increased serum levels of brain derived proteins, such as $\mathrm{S} 100 \beta$ after brain trauma or stroke [90]. S100ß is a protein primarily synthesized in the brain by astrocyte processes and is quickly released from the brain into the blood when the BBB is disrupted. Concentration of $\mathrm{S} 100 \beta$ was found increased both in CSF and in serum of MS patients and correlated with the activity of the disease [91]. Although $\mathrm{S100 \beta}$ appearance in plasma well correlated with an opening of the BBB, it has also been shown to increase in the plasma or CSF as a consequence of other disease processes not limited to the CNS, suggesting that it could not be a biomarker specific for BBB damage [89]. The main biomarker of an opening of endothelial tight junctions is zonulin. Although not specific for the $\mathrm{BBB}$, zonulin is a protein modulating tight junctions, therefore playing a potentially crucial role in the modulation of BBB permeability in MS. Elevated serum levels of zonulin have been reported in RRMS patients who had Gd-enhancing lesions and SPMS compared to controls [92]. Further studies are needed to confirm the utility of this protein as a biomarker of BBB disruption in MS. Adhesion molecules are normally expressed at very low levels on vascular endothelial cells, but after cytokine stimulation they are upregulated and released as soluble forms. Although several cell adhesion molecules (CAMs) have been reported to be associated with BBB disruption, none are in fact specific 
or highly predictive of BBB damage $[93,94]$. Other soluble adhesion molecules, such as PECAM-1, P-selectin and E-selectin, have been shown to be upregulated in RRMS patients when compared to PPMS and their levels are also upregulated during relapse, suggesting that these molecules might be used as a biomarker for BBB disruption $[95,96]$.

\subsection{Biomarkers associated with BBB damage}

Multiple studies have evaluated the potential correlation of biomarkers associated to BBB disruption, including inflammation biomarkers, such as cytokines, chemokines and their receptors, immune cell subsets, costimulatory molecules, antibodies, matrix metalloproteases (MMPs) and their natural tissue inhibitors (TIMPs). These molecules that regulate the integrity of the BBB and invasion of inflammatory cells into CNS appear to have expression changes in patients with MS. Another kind of biomarkers associated with BBB damage is endothelial-derived MVs (EMVs), shedding from cerebral endothelial cells, activated by proinflammatory cytokines and chemokines. Furthermore, changes in composition as well as function of miRNAs in body fluids or in different cell populations of MS patients seem to be particularly accurate biomarkers of MS activity.

\subsubsection{Inflammation biomarkers}

Several proinflammatory cytokines appear to be correlated with BBB disruption. Elevated TNF- $\alpha$, IL-1 beta, receptor activator of nuclear factor kappa-B ligand (RANKL) and C-reactive protein levels in serum and CSF have been associated with onset of MS relapse $[97,98]$. Studies of MS patients highlight that numerous aspects of their immune systems are dysfunctional. Evidence supports abnormal activity of T and B cells, secreted antibodies and complement activation [99]. Recent evidence also supports dysfunction of dendritic cells, macrophages and NK cells [100]. CD4 ${ }^{+}$T cells can be divided into main subsets, based on their patterns of cytokine production: Th1 (proinflammatory activity with IFN- $\gamma$, IL-12 and TNF- $\alpha$ secretion), Th2 (immunoregulatory activity with IL-10 and IL-4 secretion), Th17 (inflammatory IL-17 and IL-6 secretion) and Treg (TGF-beta and IL-10 secretion). Much attention has highlighted the over-activity of Th1 and Th17 cells that secrete proinflammatory cytokines [101]. IL-17F is one of the signature cytokines of Th17 cells that play a key role in the defense against pathogens and autoimmunity [102] and is a key determinant of aberrant immune responses in MS [103]. IL-17 production is increased in relation to disease activity, and decreased by IFN- $\beta$ therapy [104]. In particular, IL-17 levels are higher in patients recently diagnosed with MS compared to those with longstanding disease, which may relate to recent or severe disease activity [104]. It also appears to be loss of activity of regulatory T cells that normally keep inflammation in check [105]. A population of $\mathrm{CD}^{+} \mathrm{T}$ cells expressing FoxP3 that exert immunoregulatory effects on activated $T$ cells and DC has been described. The number and activity of regulatory $\mathrm{T}$ cells are reduced in the serum and CSF during acute MS relapse [106]. IL-6 serum levels were found to significantly correlate with the relapse frequency in female MS patients and with age at onset for all MS patients [107]. Since chemokines and their receptors are differentially expressed on various cell types and under various conditions, their regulation appears to drive the traffic of inflammatory cells to the CNS and thereby could correlate with BBB disruption. In a recent study, plasma levels of pentraxin 3 (PTX3), essential component of the innate immune system whose blood level is low in normal conditions, were significantly increased during the relapse stage, and had a borderline significant correlation with EDSS scores [108]. In remission, plasma PTX3 levels were lower and had no association with EDSS scores, confirming that plasma PTX3 level can be a potential biomarker of disease activity [108]. In general, cytokine/chemokine levels in MS patients also overlap with healthy subjects, as well as across disease types and courses. This is likely explained by the fact that changes in cytokine serum levels reflect a complex and intricate regulatory system for immune processes, rather than mere BBB disruption alone. Multiple studies have evaluated the potential correlation of MMPs and TIMPs involved in BBB disruption. The balance between MMPs and their TIMPs tightly regulates the digestion of the extracellular matrix and basement membranes, and thereby the migration of white blood cells to the CNS and other organs. Higher levels of MMP-9 or lower levels of TIMP-1 seemed to predict the presence of Gd-enhancing lesions and thus BBB disruption [109]. Because MMP-9 and TIMP-1 levels fluctuate within and between patient cohorts, and are affected by infections, their use for a monitoring of the disease course in MS is complex [89]. Osteopontin (OPN) is a member of the small integrin-binding ligand $\mathrm{N}$-linked glycoprotein family of non-collagenous matricellular proteins [110] and plays a role in chemotaxis, leading to the migration of macrophages and DC to sites of inflammation [111]. Since the identification of OPN as the most abundantly expressed cytokine in MS lesions, several studies have confirmed the involvement of this molecule in MS [112]. The role of OPN in inflammatory diseases of the brain has been provided by work on EAE in mice [113], in which OPN induced relapses and disease progression through enhanced survival of activated T cells [114]. On the other hand, OPN-deficient mice were resistant to developing severe EAE [112]. Plasma OPN levels were found to be increased in active RRMS $[115,116]$ just prior to the appearance of Gd-enhancing lesions [117]. Plasma OPN was further elevated in SPMS but not in PPMS [115], suggesting a role of OPN in acute and chronic disease activities. Optimal T cell activation is a complex and multistep phenomenon resulting from specific antigen recognition and interaction between pairs of costimulatory molecules on the surfaces of both APC and T lymphocytes [118]. Aberrant expression of costimulatory molecules and their receptors on peripheral blood mononuclear cells (PBMC) was found in MS patients and many studies attempt to correlate their expression levels to the status of disease. A pivotal role in T lymphocyte stimulation is played by the B7 family of costimulatory molecules [119]. Levels of the Th1 stimulatory molecule CD80 increase during active MS, while expression of the immunoregulatory CD86 molecule declines [120]. Several authors have reported that autoreactive T cells in MS are less dependent on CD28-mediated costimulation: MBP-reactive T cells from MS patients were able to be activated in the absence of CD28/B7 costimulatory pathway and blockade of CD28 failed to inhibit MBP-specific T cell proliferation in MS patients, but not in healthy subjects [121]. This evidence suggests that CD28 expression progressively declines with repeated stimulations, leading to the generation of $\mathrm{CD} 28^{-} \mathrm{T}$ cells. Other members of the B7 family have been more recently described [122]. Among molecules that negatively regulate immune responses studied in MS, a new member of the B7-CD28 superfamily, termed programmed death (PD)-1 (CD279), expressed on lymphocytes and macrophages, has been described with its ligands (PD-L1 and PD-L2) on immune cells and nonhematopoietic cells $[123,124]$. PD-1/PD-L1 or PD-1/PD-L2 interaction inhibits T cell proliferation, cytokine production, and cytolytic function, maintaining peripheral immune tolerance. It has been shown that in EAE PD-1, PD-L1 and PD-L2 are expressed on cells infiltrating the brain, and blockade of PD-1 causes augmentation of EAE [125]. Recently, it was found that the increased expression of PD-1 and PD-L1 that results in higher IL-10 production, lower proliferation, and increased apoptosis of MBP-specific lymphocytes, is associated with disease remission in MS patients, suggesting that the PD-1/PD-L1 costimulatory molecule expression on immune cells may be an interesting inflammatory biomarker [126]. In addition to CD28 costimulation, several molecules belonging to the TNF receptor superfamily, including 4-1BB (CD137; ILA/4) and its ligand 4-1BBL (CD137L), can function as costimulatory molecules for the induction, differentiation and survival of immune cells [127]. 4-1BB is a transmembrane protein receptor expressed by a variety of different cells, including B cells, macrophages and DC, activated T lymphocytes, NK cells and CD4 ${ }^{+} \mathrm{CD} 25^{+}$Treg cells [127-129]. In a study, increased soluble 4-1BBL levels were found in peripheral blood of RRMS patients compared with healthy subjects 
[130]. However, a significant correlation between soluble 4-1BBL protein levels and 4-1BBL surface or mRNA expression levels in the monocytes or PBMC was not found, suggesting that the soluble form of the molecule is probably produced by proteolytic cleavage from the cell surface form and more studies are required to establish its utility as biomarker [130]. Many studies in MS also investigated the expression of apoptosis-inducing ligand and receptor molecules, such as Fas and FasL, involved in eliminating autoreactive lymphocytes by apoptosis, to maintain the immune tolerance. There is a large body of evidence suggesting that apoptosis is defective in MS, leading to inappropriate persistence of autoreactive lymphocytes and continuing inflammation in CNS tissue [131]. Increased expression of Fas and FasL has been reported in MS lesions and on peripheral blood lymphocytes [132,133]. High systemic [134,135] and CSF [136] levels of soluble Fas protein have been detected in MS patients. Furthermore, both activated T cells and $\mathrm{T}$ cell lines derived from MS patients showed less spontaneous apoptosis and were less sensitive or even resistant to induced apoptosis, which is suggestive of a defective functioning of Fas or its downstream mechanisms in MS [137]. In RRMS patients, FasL mRNA level was increased prior to the exacerbations, but it decreased during clinical activity, while mRNA level of Fas increased. These findings suggest that the imbalance between Fas and FasL is related to clinical activity [138]. Furthermore, the serum level of Fas, FasL and another pro-apoptotic molecule belonging to TNF- $\alpha$ superfamily, tumor necrosis factorrelated apoptosis inducing ligand (TRAIL), in MS patients with different clinical forms, RRMS, in remission and relapse phase, and PPMS has been investigated [135]. Meanwhile serum levels of Fas and FasL did not differ between MS patients and healthy controls, soluble TRAIL levels were significantly decreased in RRMS during relapses [135]. These findings support a role of TRAIL in the pathogenesis of MS, especially during the acute phases of the disease and as disease activity biomarker. There is emerging evidence that the downstream antiapoptotic regulator survivin, a member of the inhibitor of apoptosis family of proteins, is over-expressed in activated $\mathrm{T}$ lymphocytes from MS patients [139]. Survivin was found to be increased during active disease and down-regulated by IFN- $\beta$ therapy, suggesting its potential role as biomarker $[140,141]$. Lymphocyte function is regulated by a network of ion channels and transporters in the plasma membrane of $\mathrm{B}$ and $\mathrm{T}$ cells. These molecules modulate the cytoplasmic concentrations of diverse cations, such as calcium, magnesium and zinc ions, which function as second messengers to regulate crucial lymphocyte effector functions, including cytokine production, differentiation and cytotoxicity [142]. In particular, the potassium channel K2P5.1 has been found to be upregulated in T cells of MS patients during acute relapse. Indeed, the pharmacological blockade of K2P5.1 or knocking down with short interfering RNA (siRNA) resulted in reduced T cell functions [143]. These results suggest that this potassium channel may represent a disease activity biomarker. A very recent study indicates an association between anti-EBNA-1 IgG levels and MS disease activity in addition to conversion from CIS to RRMS [144]. In particular, an increasing level of anti-EBNA-1 IgG associated with increased MRI disease activity has been shown [144].

\subsubsection{Microvesicles}

Much research has focused on the potential of MVs as biomarkers. MVs are a heterogeneous population of membrane-derived vesicles released by a diverse cell types upon activation or apoptosis, particularly under conditions of stress or injury. They express antigens specific of their parental cells and may be useful as biomarkers of endothelial dysfunction, coagulation, inflammation and other pathological processes [145]. MVs may be distinguished in different classes of extracellular vesicles (i.e. microparticles, exosomes, apoptotic bodies) on the basis of size, content and mechanism of formation [146-148]. MVs play a role in regulating various biological and physiological processes, including cell-cell communication, cell proliferation, coagulation, and inflammation [149]. Since MVs readily circulate in the vasculature, they may serve as shuttle signaling transducers that modulate biological processes not only in their local environment but also at remarkable distance from their site of origin. Furthermore, MVs have been implicated to have pathological roles in many diseases, such as rheumatoid arthritis, vascular diseases, cancer, diabetes, and Alzheimer's disease [150-153]. In the CNS MVs, released by nearly all cell types, have been detected in the CSF $[154,155]$ and have been implicated in neuronal development, synaptic activity, nerve regeneration, and protective mechanisms [156]. It is becoming increasingly evident that CNSderived MVs may contribute to the onset and progression of some neurodegenerative and neuroinflammatory diseases [157-159]. MVs can be isolated from the plasma or the CSF of patients suffering from several different CNS diseases and can be used as biomarkers allowing earlier detection and monitoring of the progression of diseases. To date, few studies have examined MV populations in CSF during MS disease onset and progression $[155,160]$, meanwhile several studies have been investigated circulating EMVs in blood from MS patients, as biomarkers for BBB damage, in particular during disease exacerbation [161-163]. In particular, flow cytometric studies have been revealed that the concentration of $\mathrm{CD}_{51}{ }^{+}$(vitronectin receptor) EMV was higher in relapse and remission, meanwhile CD $31^{+}$EMVs were higher in relapse and returned to nearly control value during remission [162,163]. These data suggest that a high rate of $\mathrm{CD} 31^{+}$EMVs in plasma, associated with contrast-enhancing lesions on brain MRI, could be a biomarker of exacerbation, reflecting acute endothelial damage. Furthermore, emerging evidence suggests that EMVs in MS patients promote the migration of monocytes and lymphocytes through the BBB and assist with the formation of demyelinating lesions [164]. Circulating MVs can be released not only by endothelial cells but also by platelets, erythrocytes and by immune cells and recently, MVs derived from these subtypes were assessed with flow cytometry in MS [165]. It has been shown that RRMS patients have the highest levels of MVs derived from three subtypes (platelets, total leukocytes or monocytes) while SPMS patients presented similar levels to those of healthy subjects. These results suggest that circulating MVs reflected disease status with an increment of their shedding during inflammatory periods and turning to baseline during chronic progressive degeneration [165]. Recently, we purified blood-derived MVs by size-exclusion chromatography from RRMS patients, in active- or remitting-phase of the disease, and healthy subjects. MV protein content has been undergone by a proteomic analysis and classified according to Gene Ontology. A statistically significant enrichment in proteins involved in synaptic transmission has been detected only in MV from MS patients in the active phase, but no in MS patients in remission phase and healthy subjects. Since many of these identified MV proteins are typically of the CNS, these data indicate that the origin of MVs reflects local CNS damage (personal communication). MVs can carry numerous autoantigens implicated in autoimmune diseases, including heat shock proteins (HSPs), histones, and $\alpha$-enolase, that they may be targets of autoreactive recognition. For this reason, MVs may be capable of triggering or maintaining pathological autoimmune responses [166] and constitute a useful biomarker of systemic cell activation in MS, as well as in other autoimmune diseases. In conclusion, MVs are potentially vital contributors to inflammation, by carrying autoantigens, danger signals, cytokines, lipid mediators and tissuedegrading enzymes, having pivotal roles in the initiation, propagation and regulation of inflammatory diseases. Despite the exciting potential of MVs as a source of biomarkers in various clinical applications, many challenges remain. In particular, a major limitation in this evolving discipline is the lack of standardization for already challenging techniques to isolate, characterize and detect MVs [167].

\subsubsection{MicroRNA}

MicroRNAs, a class of non-coding single-stranded RNAs approximately 22 nucleotides in length, have recently been discovered to be modulators of post-transcriptionally gene expression, either by targeting mRNA degradation or by inhibition of protein translation. 
MiRNAs play important roles in various biologic processes such as cell proliferation, development, differentiation, metabolism, apoptosis, angiogenesis, inflammation and immunity $[168,169]$. It was estimated that about one-third of human genes are negatively regulated at posttranscriptional levels by miRNAs [170], either through the inhibition of translation initiation and elongation or by destabilization of target mRNAs [171,172]. Aberrant miRNAs' expression and function are associated with several human diseases, including cancer, neurodegeneration and autoimmunity and potentially serve as diagnostic, and prognostic biomarkers or therapeutic targets [173]. miRNAs control several aspects of immunity related to the function of granulocytes, monocytes, macrophages, dendritic and natural killer cells, and to the differentiation and activation of T and B cells. Several studies performed miRNA profiling in MS patients and control subjects using PBMC [174-176], whole blood [177,178] and brain lesions [179]. All reports showed altered miRNA expression profiles in MS patients compared to healthy subjects. In particular, analyzing the expression patterns of 364 miRNAs in PBMC from MS patients in the active phase of disease, in the remission phase and in healthy subjects, a specific miRNA signature of the relapse phase has been found [174]. This specific miRNA signature consisted in a strong dysregulation of miR-18b and miR-599, whereas a strong dysregulation of miR-96 levels, involved in immunological pathways such as the interleukin signaling pathway, was observed in the remission phase [174]. Another study focused on immunologically relevant miRNAs, such as miR-21, miR-146a, miR$146 \mathrm{~b}$, miR-150 and miR-155, investigating their respective levels in PBMC from untreated MS patients compared with healthy subjects [175]. A statistically significant increased expression of miR-21, miR146a and miR-146b in RRMS patients in the active phase has been observed, compared with controls. In contrast, no differences were found in the expression levels of both miR-150 and miR-155, highlighting the possibility of defining different disease entities with specific miRNA profiles [175]. There are growing evidences that Th17 cells are key players in various autoimmune diseases, including MS [180]. In a recent study, miR-326 expression in PBMC was shown to correlate with disease severity in MS patients and mice with EAE [181]. In vivo, silencing of miR-326 resulted in fewer Th17 cells and a milder EAE, while its over-expression resulted in more Th17 cells and a severe EAE [182]. In another study, it was found that miR-155 expression was highly correlated with disease severity in MS patients and mice with EAE [183]. In particular, it was found that the knockdown of miR-155 in mice resulted in highly resistant to EAE development [183] suggesting that this kind of miRNA, promoting inflammatory properties of T cells, including Th17 and Th1 cells, is involved in MS pathogenesis. Therefore, miR-326 and miR-155 may be useful as biomarkers of disease activity. Cell-free miRNA can be detected in several human body fluids including plasma, serum, urine, and saliva [184,185]. Some miRNAs circulating in the blood have been identified as biomarkers in different human diseases such as cancer, cardiovascular diseases and brain injury [186, 187], because they correlate with disease activity and prognosis, particularly in cancer. Interestingly, circulating miRNAs are exceptionally stable in biological fluids, suggesting that miRNAs are released from cells in MVs (in particular exosomes) that protect them from blood RNase activity [186]. Current knowledge of the biological significance of cell-free miRNA, especially with respect to intracellular miRNA, is still very limited. A preliminary study evaluated the expression of selected microRNA (miR-let-7a, miR-92a, and miR-648a) in the plasma of patients with MS during a relapse as well as in remission and healthy subjects and attempt to correlate the acquired data with clinically relevant parameters of the disease [188]. These results suggested that more studies are necessary to define which miRNA subsets may be potential biomarkers for MS. Furthermore, various studies analyzed the expression of miRNAs in immune cells of RRMS patients without distinguishing between active or remission phase. It was found that miR-17-5p, miR-92, miR-193a and miR-497 were deregulated in RRMS patients compared to the healthy subjects [189]. In particular
MiR-17-5p, regulating different stages of lymphocyte development, activation and survival [189] and having roles in the development of autoimmune and lymphoproliferative diseases in mice [190], was upregulated in $\mathrm{CD}^{+} \mathrm{T}$ cells but downregulated in $\mathrm{B}$ cells of RRMS patients. Analysis of miRNAs in Treg $\mathrm{CD}^{+}$cells, that lose their capacity to suppress the activation of the immune system, showed that miR-106, miR-25, miR-19a and miR-19b significantly upregulated in RRMS patients versus controls [191]. These miRNAs modulate the TGF- $\beta$ signaling pathway, silencing the cell cycle inhibitor CDKN1A (p21) and the pro-apoptotic gene BCL2L11 (BIM) [192]. These results suggest that the disruption of TGF- $\beta$ pathway, involved in the maintenance of self-tolerance and $\mathrm{T}$ cell homeostasis, may be one way by which miRNA alteration promotes MS development [191].

\section{Biomarkers of disease progression}

Several years after the disease onset, when the RRMS patients have reached a threshold level of irreversible neurological symptoms, and when functional compensation may be exhausted, the clinical features of the disease change, heralding the onset of SPMS [193,194]. Epidemiological and MRI studies indicate that the RRMS to SPMS phase transition can be mainly driven by the prevalence of neurodegenerative over inflammatory pathological features [195]. Thus, therapies that target the adaptive immune response on SPMS show limited efficacy $[195,196]$ and at present, there are no useful disease-modifying treatments for SPMS and PPMS. In the same time, some evidence suggests that the other progressive course of the disease, PPMS, represents a distinct, non-inflammatory or at least less inflammatory pathologic form of the disease $[197,198]$. Multiple mechanisms contributing to neurodegeneration in PPMS or SPMS are currently unresolved, including exhaustion of functional compensation, lack of trophic support, chronic microglial activation, mitochondrial injury, oxidative stress and altered expression of ion channels in demyelinated axons [197, 199-201]. Following damaging processes, molecules released from CNS cells are liberated into the extracellular compartment and finally in the CSF and blood $[202,203]$. These released molecule debris may be able to reach the peripheral lymph nodes, leading to autoimmune responses toward these antigens that might contribute to CNS damage [204]. Indeed, IgG and IgM antibodies binding to the surface of a neuronal cell line were found in 70\% of sera from SPMS patients and in $25 \%$ of sera from RRMS patients [205]. This finding may indicate the spreading of autoimmunity to neuronal antigens as a consequence of CNS tissue damage, and the expansion of pathology from moderate to marked neuroaxonal loss associated with a transition from RRMS to SPMS course. Promising biomarkers for monitoring neuro-axonal damage and conversion to chronic progressive MS are serum neurofilament proteins and antibodies directed against the cytoskeleton. Neurofilaments (NFs) are major components of the axonal cytoskeleton, which exist as heteropolymers of low (NFL), medium (NFM), and high (NFH) molecular weight protein subunits. NFs represent candidates for prognostic biomarkers of the MS course because their detection in blood or CSF reflects neuronal and axonal damage [206-208]. There are contrasting results regarding serum NFL in MS. The highly phosphorylated NFH (pNFH) are normally found only in axonal NFs and this biomarker is thought to indicate axonal injury [206], whereas NFL constitutes only a minor part of the neuronal cell body and dendrites relative to axons [209]. Recently, it has been shown that serum pNFH levels can be detected more likely in SPMS than RRMS, indicating that the routine measurement of serum pNFH should be a prognostic indicator of disease outcome [210]. Furthermore, the presence of serum pNFH is associated with higher disease severity scores and T2 cerebral MRI lesion load, supporting the hypothesis that serum pNFH levels are likely to reflect CNS axonal injury [26,210]. Recent studies reported the involvement of antibodies specific to NFL in axonal pathology in MS, in which NFL antibodies correlated with clinical disability and progressive disease course of MS, as well as with MRI markers of cerebral 
atrophy [211]. Furthermore, serum anti-NFL IgG levels were found to be significantly increased in PPMS patients, compared to other neurological diseases or healthy subjects $[211,212]$. In addition to NFs, the other major component of the axonal cytoskeleton is the microtubule, which mainly consists of $\alpha$ and $\beta$ tubulin subunits [207], and microtubule-associated proteins (MAPs), such as MAP2 and tau [213]. In one study, CSF antibodies to tubulin and the CSF/serum antitubulin index correlated significantly with EDSS in one study [212], whereas no similar correlations with disability were found in another study $[214,215]$. As reported below, an aberrant N-glycosylation is a fundamental determinant of autoantibody recognition in MS. It was found that the serum antibody titers against a synthetic glycopeptide termed CSF114(Glc) paralleled clinical activity and brain lesions positive to MRI, suggesting that CSF114(Glc)-based immunoassay on sera may have a high prognostic value in detecting and monitoring disease progression [216]. Recently, antigen microarray analysis was used to characterize patterns of serum antibody reactivity in MS, against a panel of CNS antigens and lipid autoantigens and HSPs [217]. This approach revealed unique autoantibody signatures in clinical and pathologic subtypes of MS, that distinguished RRMS, SPMS and PPMS from healthy controls and other neurologic or autoimmune diseases [217]. In particular, RRMS was characterized by autoantibodies to HSPs, augmented in response to inflammation and upregulated in MS lesions, that were not observed in PPMS or SPMS. In addition RRMS, SPMS, and PPMS were characterized by unique patterns of reactivity to CNS antigens [218,219]. These data suggest that antibody signature appears to reflect immune processes in the CNS, thus antigen arrays may provide promising tool for monitoring the progression of the disease. Furthermore, many different immune mediators, such as cytokines, chemokines, apoptotic molecules, may have a prognostic value for the clinical evolution of MS. It has been reported that cell surface Fas and FasL predict slower long-term disability progression in MS [220]. In particular, high levels of Fas mRNA were associated with a favorable disease course in RRMS, as measured by EDSS, meanwhile high levels of FasL mRNA were associated with relatively mild disease progression in SPMS [220]. The pro-inflammatory cytokine TNF- $\alpha$ has been associated with MS disease activity and implicated in axon degeneration [221]. A selective increase of soluble TNF-receptor II (sTNF-RII) levels in PPMS patients, was shown compared with patients with other clinical forms of the disease and healthy subjects [222]. Although TNF-RII levels significantly increased over a 2-year follow-up period in a subgroup of PPMS patients, they could not discriminate between patients with and without disability progression [222]. Compounds deriving from overproduction of reactive oxygen, reactive nitrogen species and metabolites generated by altered energy metabolism might be detected in excess in blood samples from MS patients. Great attention has been given to alterations in mitochondrial functions. A recent multicenter study found a linear correlation between serum lactate levels and EDSS [223], meanwhile in another study no correlation between CSF lactate measure and the disease progression on EDSS or with the clinical subtype (RR, SP, PP) was found [224]. Since impaired mitochondrial functioning has been hypothesized to drive neurodegeneration increasing anaerobic metabolism in MS, the lactate produced during anaerobic energy metabolism might be a biomarker for neurodegeneration. Circulating miRNAs are differentially expressed in RRMS and SPMS versus healthy subjects and in RRMS versus SPMS and linked to EDSS and disease duration [225]. In particular, let-7 miRNA family, potent activators of toll-like receptor signaling in macrophages and microglia and regulating stem cell differentiation and neurogenesis, differentiated SPMS from healthy subjects and RRMS from SPMS [225]. Interestingly the same circulating miRNA (let-7), expressed both in SPMS and amyotrophic lateral sclerosis (ALS) patients but differentially expressed in RRMS patients, suggests that similar neurodegeneration processes may occur in SPMS and ALS [225]. Recently, a statistically significant downregulation of miR-15b and miR-223 in PPMS patients, suggesting that the profiling of these miRNAs may be considered a biomarker to distinguish patients with different subtypes and stages of MS, has been shown.

\section{Biomarkers of therapeutical response}

The therapy of MS is rapidly evolving. Several therapeutic agents are available, and many others are at an advanced stage of development. For this reason, the discovery of biomarkers to identify non-responder patients to drug therapy is essential in tailoring the best treatment. Currently, several different treatments for MS patients with different mechanisms of action and dissimilar side effect profiles exist, including intramuscular IFN- $\beta$ 1-a (Avonex $\left.{ }^{\circledR}\right)$, subcutaneous IFN- $\beta$ 1a (Rebif $\left.{ }^{\circledR}\right)$, subcutaneous IFN- $\beta$ 1b (Betaseron/Extavia $\left.{ }^{\circledR}\right)$, glatiramer acetate (Copaxone ${ }^{\circledR}$ ), natalizumab (Tysabri ${ }^{\circledR}$ ), fingolimod (Gilenya ${ }^{\circledR}$ ), teriflunomide (Aubagio $\left.{ }^{\circledR}\right)$, dimethylfumarate (Tecfidera ${ }^{\circledR}$ ), alemtuzumab (Lemtrada ${ }^{\circledR}$ ) and mitoxantrone (Novantrone ${ }^{\circledR}$ ) [226]. IFN- $\beta$ (IFN) is one of the most widely used treatments for MS. However, a major limitation with IFN is that MS patients, in a range between 30 and 50\%, do not respond to the therapy [227], thus biomarkers for monitoring of IFN therapy have recently been studied intensively. The search for a biomarker of IFN response has proven even more difficult, since the precise mechanism of action in MS remains unclear. IFN effectiveness is probably attributable to numerous immunomodulatory activities, including altering the Th1/Th2 balance [228,229], antiproliferative effects on T-cell expansion, differentiation and increased T cell apoptosis [230]. There is also evidence that IFN inhibits transmigration of immune cells across the BBB [231]. IFN treatment may induce immunogenicity reactions in the form of binding and neutralizing antibodies (bAbs and nAbs, respectively) [232]. Between 2\% and 45\% of people treated with IFN will develop nAbs, and this is dependent on the specific drug and dosing. However, much controversy remains regarding the loss of the clinical efficacy of the therapy induced by these antibodies and thus the need for incorporation of nAbs testing into clinical practice [233]. Gene-expression changes occurring in response to IFN binding to its receptor have been useful in finding biomarkers that explain IFN bioactivity. Among the different IFNresponsive genes, myxovirus resistance protein A (MxA), a GTPase protein encoded by the MX1 gene with potent antiviral activity [234], has proven to be one of the most sensitive and specific biomarkers of IFN bioactivity [234]. MxA expression is significantly reduced during the development of nAbs [235,236], and its measurement has provided the basis for in vitro and in vivo assays to determine the presence of nAbs [237]. However, there is a lack of clear roles of MxA as a biomarker on disease pathogenesis or in the therapeutic response to IFN [238-241]. A recent study demonstrated that measurements of both MxA and nAbs after one year of IFN treatment were predictive for the risk of new relapses [242], suggesting that MxA may be useful as a biomarker for the pharmacological response of IFN. Several serum molecules involved in the mechanisms of IFN action have been proposed as biomarkers for IFN therapy, although none have been confirmed to date. Among them, soluble TRAIL (sTRAIL), which is able to inhibit autoreactive and antigen specific T cells, has been shown to be induced by IFN in T cells [243,244], NK cells [245] and monocytes [246]. sTRAIL mRNA level has been proposed as a response biomarker for IFN treatment, although its precise role is not completely understood $[247,248]$. Other potential candidates as IFN therapy biomarkers are CXCL-10/IP-10 and CCL-2/MCP-1 chemokines, both involved in the recruitment of leukocytes (249). As well as MMP-9 and TIMP-1, involved in regulation of leukocyte trafficking across the BBB [249,250, 251], IFN, decreasing the expression of MMP-9, leads to a reduction of T-lymphocyte infiltration into the CNS [231,252]; on the other hand, MMPs diminish the response to therapy through proteolytic cleavage of the IFN peptide [253]. IFN has been shown to down regulate mRNA and protein expression of MMP9 [254,255], and to upregulate the levels of its physiological inhibitor TIMP1 [256]. These studies suggest that 
MMPs may be considered as potential biomarkers for response to IFN treatment. Additional biomarkers of IFN bioactivity include IFN receptors (IFNARs). Ligand binding to the two IFNRs (IFNAR1 and IFNAR2) results in a ternary complex that becomes internalized and degraded [257]; therefore, decreased IFNAR expression is indicative of the bioavailability of IFN. In a study of 219 MS patients receiving IFN therapy, patients responding to treatment showed significantly downregulated IFNAR expression compared with non-responders or controls [258]. In a study, examining IFNAR2 splice variants, the long-term treatment with IFN significantly correlated with decreased mRNA levels of the transmembrane isoforms (IFNAR2b and -2c) [259]. Another series of studies on large-scale gene expression profiling have revealed that clinical non-responders exhibit altered expression of IFN-response genes, both at baseline and after IFN treatment [260,261]. In particular, these studies have revealed that a number of genes related with the mitochondrial function and several processes such as protein synthesis and antigen presentation were found to be differentially expressed in monocytes from IFN non-responders [262]. Furthermore, the baseline expression of the interleukin-1 receptor-associated kinase 3, a negative regulator of TLR4 signaling primarily expressed in monocytes, was found to be significantly decreased in IFN responders compared with non-responders [263]. These differentially expressed genes during IFN treatment may predict the therapy response. Other relevant signaling pathways that were upregulated in IFN non-responders were related with high serum levels of IL- $17 \mathrm{~F}$ at baseline that have been associated with suboptimal response to IFN in RRMS patients [103,264]. In a series of experiments, it was found that mice with Th1-EAE benefit from IFN treatment with reduction in levels of disability, while mice with Th17-EAE do not respond and disease worsens [265]. Indeed, in RRMS patient studies, IFN non-responders had higher IL-17F concentrations in serum compared to responders and non-responders had worse disease with more relapse risk than did responders [103]. Hence, high IL-17F concentration in the serum of RRMS patients is associated with non-responsiveness to IFN therapy. Furthermore, these patients also had high levels of endogenous IFN- $\beta$ compared to responders. These data suggest that high IL-17F and IFN- $\beta$ concentrations may be considered as predictive biomarkers of IFN therapy's efficacy [103]. Sensitive bioassays of the serum endogenous IFN- $\beta$ may be used to identify RRMS patients with low endogenous IFN- $\beta$ levels that will likely optimally respond to IFN treatment [260], whereas RRMS patients with higher endogenous IFN- $\beta$ levels may be stratified for other currently available immunomodulatory therapies [266]. Recently, a novel study about measure of serum IL-17 in MS showed discordant results [104], probably because of different methodologies to detect serum cytokine. In this study, the role of IL-17F in predicting treatment response to IFN was investigated analyzing serum samples collected at baseline and after 6 months of treatment [104]. The results showed that an increase of IL-17F before and early after IFN treatment was not associated with poor response, excluding patients with neutralizing antibodies. These data suggest that the value of IL- $17 \mathrm{~F}$ is not a treatment response indicator for therapy, although high levels of IL-17F greater than $200 \mathrm{pg} / \mathrm{mL}$ may predict non-responsiveness [104]. IL-10 is an immunoregulatory cytokine produced by Th2 cells. Systemic IL-10 decreases prior to clinical and MRI relapse, and increases when disease activity resolves $[267,268]$. Treatment with IFN or glatiramer acetate, a random polymer of four amino acids found in myelin basic protein working as a decoy for immune system, augments systemic IL-10 activity [269, 270 ], thus lower baseline serum levels of IL-10 predict clinical response to IFN [271]. Indeed, patients who continue to have clinical relapses and MRI activity after IFN treatment had a paradoxical decrease in serum IL10 levels [272]. Multiple studies have also found that the ratio of IL-10/ IL-12 correlates with disease activity, and increases with IFN treatment in patients who respond to therapy, suggesting that these cytokines may be used as biomarker for therapy response [272]. As reported below, endothelial-derived MVs are associated with BBB damage. A first prospective study in a cohort of RRMS patients revealed a significantly reduction of plasma levels of $\mathrm{CD} 31^{+}$EMVs after IFN treatment [273]. Findings in a second cohort of MS patients, treated with high doses of INF and followed-up for one year, showed that the decrease in plasma levels of $\mathrm{CD} 31^{+}$and $\mathrm{CD} 54^{+}$EMV at 12 months was associated with a significant decrease in the number and volume of contrast enhancing T1-weighted lesions [274]. Many studies about genome-wide expression profiles were carried out in peripheral immune cells, comparing MS patients and healthy subjects. It has been repeatedly demonstrated that IFN-mediated gene-regulatory effects can be accessed by expression profiling of peripheral blood cells using DNA microarrays [275,276]. Few high-throughput analyses have been completed in an attempt to characterize the transcriptional changes in the blood that occur in response to IFN. In a study, after the first dose and upon chronic dosing of IFN, nearly 4000 genes were measured, of which about 1500 were identified as up- or down-regulated [277]. It has been shown that IFN induces changes in the expression of many genes, such as cytokines and cell adhesion molecules. In particular, Jak-STAT, TNFRSF10B, IL6, TGF- $\beta$, retinoic acid and CDC42 pathways were found to be modulated by the therapy [277]. In another study, genome-wide expression profiles of PBMC of 24 MS patients within the first 4 weeks of IFN administration were obtained, by using Affymetrix DNA microarrays [278]. About 121 genes were significantly up- or down-regulated compared with baseline, with stronger changed expression at one week after start of therapy. A network region of genes associated to therapeutic side effects was linked to NF-kB activity [278]. These genome-wide association studies have identified genes that may be useful as biomarkers for therapy response. Additional studies have used also miRNA profiling to better understand treatment effects, with the hope of identifying biomarkers of therapeutic response [279]. In particular, the expression of several selected immunologically relevant miRNAs in PBMC derived from RRMS patients and healthy subjects to evaluate the impact of immunomodulatory therapy, such as GA and IFN, on miRNA expression, has been analyzed. One of these studies showed that the reduction of miR-29 was associated with IFN response [280]. In RRMS patients treated with GA, two miRNAs (miR-146a and miR-142-3p) appeared to be reduced with respect to control levels when compared with those of untreated or IFN-treated MS patients [281]. Recently, a study based on measuring the expression of 651 miRNAs and about 19,000 mRNAs in PBMC, reported that several miRNAs, including miR-16-5p and miR-342-5p, were increased, whereas 13 miRNAs, including miR-27a-5p and miR-29a-3p, were decreased in PBMC, in particular in monocytes, from RRMS patients after IFN therapy [280]. IFN did not restore the expression of deregulated miRNAs, whereas GA treatment seemed to normalize the levels of miR-146a and miR-142-3p [179,282], involved in the regulation of Treg cell function, but not miR-155 and miR-326, involved in T cell development and Th17 differentiation [186,281, 283]. A specific miRNA expression profile in B cells, mir-106b-25 and miR-17-92, after natalizumab (a humanized monoclonal antibody) treatment against $\alpha$-4-integrin subunit of very late activation antigen-4, was identified comparing treated and untreated RRMS patients, suggesting their potential utility as biomarkers for the disease course and prognosis [284]. Natalizumab is involved in leukocyte trafficking across the inflamed BBB into the CNS [285]. Nevertheless, in clinical practice natalizumab treatment is complicated by its association with progressive multifocal leukoencephalopathy (PML), which occurs in approximately $2 / 1000$ treated patients [286,287]. This is a severe and often fatal demyelinating disorder of the CNS caused by the reactivation of a latent JC virus (JCV) infection during immunosuppression that leads to a lytic infection of oligodendrocytes with progressive damage of white matter $[288,289]$. In order to identify natalizumab-treated patients at risk of developing PML, the anti-JCV antibody levels were assayed in CSF and serum [290]. At present, it is not definitively known which patients are at greatest risk for developing PML, although the risk appears to be greater in serum anti-JCV antibody positive patients who have had treatment 
for more than 24 months and who have been exposed to previous immunosuppressive therapy [291-293]. Whether JCV antibody titers are helpful to determine the individual risk is currently under investigation.

\section{Conclusions}

Pathophysiological and clinical complexity of MS inevitably leads to a great variety of potential biomarkers specific for diagnostics, prediction of disease course and optimization of therapeutic responses. Measurements of biomarkers are based on the detection of specific molecules in the body fluids that become altered as a consequence of a biologic or pathologic process. In particular, biomarkers that are measurable from the peripheral blood are of great clinical value because of the non-invasive collection method. Recent advances in proteomics along with microarray gene and antigen analysis have led to identify a whole new list of biomarkers specific for MS in blood. Several of these candidate biomarkers show promising potential both in reflecting clinical disease status and in monitoring treatment response, but so far none have the validated reliability necessary for widespread clinical use. The lack of validation, reflecting a bias in statistical analysis or a lack of available data, may also indicate difficulties in performing clinical validation studies. Therefore, large, concerted, and collaborative efforts will be needed to overcome the many obstacles that complicate the validation and clinical application of biomarkers in MS.

\section{Take-home messages}

- Recent advances in proteomics along with microarray gene and antigen analysis has led to identify a whole new list of biomarkers specific for MS in blood.

- Circulating biomarkers in peripheral blood are of growing importance in the field of diagnosis, prognosis, prediction and therapy monitoring in MS.

\section{References}

[1] Lublin FD. New multiple sclerosis phenotypic classification. Eur Neurol 2014; 72(Suppl. 1):1-5.

[2] Fox RJ, Bethoux F, Goldman MD, Cohen JA. Multiple sclerosis: advances in understanding, diagnosing, and treating the underlying disease. Cleve Clin J Med 2006; 73:91-102.

[3] Lassmann H, Brück W, Lucchinetti C. The immunopathology of multiple sclerosis: an overview. Brain Pathol 2007;17:210-8.

[4] Lucchinetti C, Brück W, Parisi J, Scheithauer B, Rodriguez M, Lassmann H. Heterogeneity of multiple sclerosis lesions: implications for the pathogenesis of demyelination. Ann Neurol 2000;47:707-17.

[5] Peterson LK, Fujinami RS. Inflammation, demyelination, neurodegeneration and neuroprotection in the pathogenesis of multiple sclerosis. J Neuroimmunol 2007; 184:37-44.

[6] Wekerle H. Lessons from multiple sclerosis: models, concepts, observations. Ann Rheum Dis 2008;67(Suppl. 3):iii56-60.

[7] Sospedra M, Martin R. Immunology of multiple sclerosis. Annu Rev Immunol 2005; 23:683-747.

[8] Kasper LH, Shoemaker J. Multiple sclerosis immunology: the healthy immune system vs the MS immune system. Neurology 2010;74:S2-8.

[9] Selmi C, Mix E, Zettl UK. A clear look at the neuroimmunology of multiple sclerosis and beyond. Autoimmun Rev 2012;11:159-62.

[10] Kurtzke JF. Rating neurologic impairment in multiple sclerosis: an expanded disability status scale (EDSS). Neurology 1983;33:1444-52.

[11] Biomarkers Definitions Working Group. Biomarkers and surrogate endpoints: preferred definitions and conceptual framework. Clin Pharmacol Ther 2001;69:89-95.

[12] Villoslada P. Biomarkers for multiple sclerosis. Drug News Perspect 2010;23: 585-95.

[13] Ioannidis JP, Panagiotou OA. Comparison of effect sizes associated with biomarkers reported in highly cited individual articles and in subsequent meta-analyses. JAMA 2011;305:2200-10.

[14] Harris VK, Sadiq SA. Disease biomarkers in multiple sclerosis: potential for use in therapeutic decision making. Mol Diagn Ther 2009;13:225-44.

[15] Bielekova B, Martin R. Development of biomarkers in multiple sclerosis. Brain 2004:127:1463-78.

[16] Liotta LA, Ferrari M, Petricoin E. Clinical proteomics: written in blood. Nature 2003; 425:905

[17] Anderson N, Polanski M, Pieper R, Gatlin T, Tirumalai R, Conrads T, et al. The human plasma proteome: a non-redundant list developed by combination of four separate sources. Mol Cell Proteomics 2004;3:311-6.
[18] Barkhof F, Simon JH, Fazekas F, Rovaris M, Kappos L, de Stefano N, et al. MR monitoring of immunomodulation in relapse-onset multiple sclerosis trials. Nat Rev Neurol 2011;8:13-21.

[19] McDonald WI, Compston A, Edan G, Goodkin D, Hartung HP, Lublin FD, et al. Recommended diagnostic criteria for multiple sclerosis: guidelines from the International Panel on the diagnosis of multiple sclerosis. Ann Neurol 2001;50:121-7.

[20] Barkhof F. The clinico-radiological paradox in multiple sclerosis revisited. Curr Opin Neurol 2002;15:239-45.

[21] Zisimopoulou P, Brenner T, Trakas N, Tzartos SJ. Serological diagnostics in myasthenia gravis based on novel assays and recently identified antigens. Autoimmun Rev 2013;12:924-30.

[22] Dalmau J, Gultekin HS, Posner JB. Paraneoplastic neurologic syndromes: pathogenesis and physiopathology. Brain Pathol 1999;9:275-84.

[23] Hinson SR, McKeon A, Lennon VA. Neurological autoimmunity targeting aquaporin-4. Neuroscience 2010;168:1009-18.

[24] Derfuss T, Meinl E. Identifying autoantigens in demyelinating diseases: valuable clues to diagnosis and treatment? Curr Opin Neurol 2012;25:231-8.

[25] Linington C, Lassmann $\mathrm{H}$. Antibody responses in chronic relapsing experimenta allergic encephalomyelitis: correlation of serum demyelinating activity with antibody titre to the myelin/oligodendrocyte glycoprotein (MOG). J Neuroimmuno 1987;17:61-9.

[26] Reindl M, Khalil M, Berger T. Antibodies as biological markers for pathophysiological processes in MS. J Neuroimmunol 2006;180:50-62.

[27] Mayer MC, Meinl E. Glycoproteins as targets of autoantibodies in CNS inflammation: MOG and more. Ther Adv Neurol Disord 2012;5:147-59.

[28] Johnson D, Hafler DA, Fallis RJ, Lees MB, Brady RO, Quarles RH, et al. Cell-mediated immunity to myelin-associated glycoprotein, proteolipid protein, and myelin basic protein in multiple sclerosis. J Neuroimmunol 1986;13:99-108.

[29] Probstel AK, Dornmair K, Bittner R, Sperl P, Jenne D, Magalhaes S, et al. Antibodies to MOG are transient in childhood acute disseminated encephalomyelitis. Neurology 2011;77:580-8.

[30] Reindl M, Linington C, Brehm U, Egg R, Dilitz E, Deisenhammer F, et al. Antibodies against the myelin oligodendrocyte glycoprotein and the myelin basic protein in multiple sclerosis and other neurological diseases: a comparative study. Brain 1999; 122:2047-56.

[31] Egg R, Reindl M, Deisenhammer F, Linington C, Berger T. Anti-MOG and anti-MBP antibody subclasses in multiple sclerosis. Mult Scler 2001;7:285-9.

[32] Berger T, Rubner P, Schautzer F, Egg R, Ulmer H, Mayringer I, et al. Antimyelin antibodies as a predictor of clinically definite multiple sclerosis after a first demyelinating event. N Engl J Med 2003;349:139-45.

[33] Doyle HA, Mamula MJ. Post-translational protein modifications in antigen recognition and autoimmunity. Trends Immunol 2001;22:443-9.

[34] Papini AM. The use of post-translationally modified peptides for detection of biomarkers of immune-mediated diseases. J Pept Sci 2009;15:621-8.

[35] Carotenuto A, D'Ursi AM, Nardi E, Papini AM, Rovero P. Conformational analysis of a glycosylated human myelin oligodendrocyte glycoprotein peptide epitope able to detect antibody response in multiple sclerosis. J Med Chem 2001;44:2378-81.

[36] Sendid B, Colombel JF, Jacquinot PM, Faille C, Fruit J, Cortot A, et al. Specific antibody response to oligomannosidic epitopes in Crohn's disease. Clin Diagn Lab Immunol 1996;3:219-26.

[37] Rieder F, Schleder S, Wolf A, Dirmeier A, Strauch U, Obermeier F, et al. Serum antiglycan antibodies predict complicated Crohn's disease behavior: a cohort study. Inflamm Bowel Dis 2010;16:1367-75.

[38] Schwarz M, Spector L, Gortler M, Weisshaus O, Glass-Marmor L, et al. Serum antiGlc(alpha1,4)Glc(alpha) antibodies as a biomarker for relapsing-remitting multiple sclerosis. J Neurol Sci 2006;244:59-68.

[39] Brettschneider J, Jaskowski TD, Tumani H, Abdul S, Husebye D, Seraj H, et al. Serum anti-GAGA4 IgM antibodies differentiate relapsing remitting and secondary progressive multiple sclerosis from primary progressive multiple sclerosis and other neurological diseases. J Neuroimmunol 2009;217:95-101.

[40] Masuoka J. Surface glycans of Candida albicans and other pathogenic fungi: physiological roles, clinical uses, and experimental challenges. Clin Microbiol Rev 2004; $17: 281-310$

[41] Hellerqvist CG, Lindberg B, Sigfrid S, Holme T, Lindberg AA. Structural studies on the O-specific sidechains of the cell-wall lipopolysaccharide from Salmonella typhimurium 395 ms. Carbohydr Res 1968;8:43-55.

[42] van Horssen J, Bö L, Dijkstra CD, de Vries HE. Extensive extracellular matrix depositions in active multiple sclerosis lesions. Neurobiol Dis 2006;24:484-91.

[43] Pender MP. Preventing and curing multiple sclerosis by controlling Epstein-Barr virus infection. Autoimmun Rev 2009;8:563-8.

[44] Ascherio A, Munger KL. Epstein-Barr virus infection and multiple sclerosis: a review. J Neuroimmune Pharmacol 2010;5:271-7.

[45] Ascherio A, Munger KL. Environmental risk factors for multiple sclerosis: part I. The role of infection. Ann Neurol 2007;61:288-99.

[46] Farrell RA, Antony D, Wall GR, Clark DA, Fisniku L, Swanton J, et al. Humoral immune response to EBV in Multiple sclerosis is associated with disease activity on MRI. Neurology 2009;73:32-8.

[47] Sundström P, Nyström M, Ruuth K, Lundgren E. Antibodies to specific EBNA-1 domains and HLA DRB $1 * 1501$ interact as risk factors for multiple sclerosis. J Neuroimmunol 2009;215:102-7.

[48] Lünemann JD, Huppke P, Roberts S, Brück W, Gärtner J, Münz C. Broadened and elevated humoral immune response to EBNA1 in pediatric multiple sclerosis. Neurology 2008;71:1033-5.

[49] Waubant E, Mowry EM, Chitnis T, Yeh EA, Kuntz N, et al. Common viruses associated with lower pediatric multiple sclerosis risk. Neurology 2011;76: 1989-95. 
[50] Knox KK, Brewer JH, Henry JM, Harrington DJ, Carrigan DR. Human herpesvirus 6 and multiple sclerosis: systemic active infections in patients with early disease. Clin Infect Dis 2000;31:894-903.

[51] Braun DK, Dominguez G, Pellett PE. Human herpesvirus 6. Clin Microbiol Rev 1997; 10:521-67.

[52] Opsahl ML, Kennedy PG. Early and late HHV-6 gene transcripts in multiple sclerosis lesions and normal appearing white matter. Brain 2005;128:516-27.

[53] Cermelli C, Berti R, Soldan SS, Mayne M, D'Ambrosia JM, Ludwin SK, et al. High frequency of human herpesvirus 6 DNA in multiple sclerosis plaques isolated by laser microdissection. J Infect Dis 2003;187:1377-87.

[54] Soldan SS, Jacobson S. Role of viruses in etiology and pathogenesis of multiple sclerosis. Adv Virus Res 2001:56:517-55.

[55] Riverol M, Sepulcre J, Fernandez-Diez B, Villoslada P, Fernandez-Alonso M Rubio M, et al. Antibodies against Epstein-Barr virus and herpesvirus type 6 are associated with the early phases of multiple sclerosis. J Neuroimmuno 2007; 192:184-5.

[56] Soldan SS, Berti R, Salem N, Secchiero P, Flamand L, Calabresi PA, et al. Association of human herpes virus 6 (HHV-6) with multiple sclerosis: increased IgM response to HHV-6 early antigen and detection of serum HHV-6 DNA. Nat Med 1997:3:1394-7.

[57] Virtanen JO, Färkkilä M, Multanen J, Uotila L, Jääskeläinen AJ, Vaheri A, et al Evidence for human herpesvirus 6 variant $A$ antibodies in multiple sclerosis: diagnostic and therapeutic implications. J Neurovirol 2007;13:347-52.

[58] Friedman JE, Zabriskie JB, Plank C, Ablashi D, Whitman J, Shahan B, et al. A randomized clinical trial of valacyclovir in multiple sclerosis. Mult Scler 2005;11:286-95.

[59] Srivastava R, Aslam M, Kalluri SR, Schirmer L, Buck D, Tackenberg B, et al. Potassium channel KIR4.1 as an immune target in multiple sclerosis. N Engl J Med 2012;367: 115-23.

[60] Achiron A, Barak Y. Multiple sclerosis - from probable to definite diagnosis: a 7year prospective study. Arch Neurol 2000;57:974-9.

[61] Brex PA, Ciccarelli O, O'Riordan JI, Sailer M, Thompson AJ, Miller DH. A longitudinal study of abnormalities on MRI and disability from multiple sclerosis. N Engl J Med 2002;346:158-64.

[62] Korteweg T, Tintoré M, Uitdehaag B, Rovira A, Frederiksen J, Miller D, et al. MR criteria for dissemination in space in patients with clinically isolated syndromes: a multicentre follow-up study. Lancet Neurol 2006;5:221-7.

[63] Tintoré M, Rovira A, Brieva L, Grivé E, Jardí R, Borrás C, et al. Isolated demyelinating syndromes: comparison of CSF oligoclonal bands and different MR imaging criteria to predict conversion to CDMS. Mult Scler 2001;7:359-63.

[64] Kuhle J, Pohl C, Mehling M, Edan G, Freedman MS, Hartung HP, et al. Lack of association between antimyelin antibodies and progression to multiple sclerosis. N Engl J Med 2007;356:371-8.

[65] Corvol JC, Pelletier D, Henry RG, Caillier SJ, Wang J, Pappas D, et al. Abrogation of T cell quiescence characterizes patients at high risk for multiple sclerosis after the initial neurological event. Proc Natl Acad Sci U S A 2008;105:11839-44.

[66] Freedman MS, Laks J, Dotan N, Altstock RT, Dukler A, Sindic CJ. Anti-alphaglucosebased glycan IgM antibodies predict relapse activity in multiple sclerosis after the first neurological event. Mult Scler 2009;15:422-30.

[67] Arrambide G, Espejo C, Yarden J, Fire E, Spector L, Dotan N, et al. Serum biomarker gMS-Classifier2: predicting conversion to clinically definite multiple sclerosis. PLoS One 2013;8:e59953.

[68] Lalive PH, Menge T, Delarasse C, Della Gaspera B, Pham-Dinh D, Villoslada P, et al. Antibodies to native myelin oligodendrocyte glycoprotein are serologic markers of early inflammation in multiple sclerosis. Proc Natl Acad Sci U S A 2006;103:2280-5.

[69] Reder AT, Oger JJ. Anti-myelin oligodendrocyte glycoprotein antibodies in multiple sclerosis. Neurology 2004;62:1922-3.

[70] Lünemann JD, Tintoré M, Messmer B, Strowig T, Rovira A, Perkal H, et al. Elevated Epstein-Barr virus-encoded nuclear antigen-1 immune responses predict conversion to multiple sclerosis. Ann Neurol 2010;67:159-69.

[71] D'Aurizio F, Villalta D, Metus P, Doretto P, Tozzoli R. Is vitamin D a player or not in the pathophysiology of autoimmune thyroid diseases? Autoimmun Rev 2015;14: 363-9.

[72] Pelajo CF, Lopez-Benitez JM, Miller LC. Vitamin D and autoimmune rheumatologic disorders. Autoimmun Rev 2010;9:507-10.

[73] Agmon-Levin N, Theodor E, Segal RM, Shoenfeld Y. Vitamin D in systemic and organ-specific autoimmune diseases. Clin Rev Allergy Immunol 2013;45:256-66.

[74] Arnson Y, Amital H, Shoenfeld Y. Vitamin D and autoimmunity: new aetiological and therapeutic considerations. Ann Rheum Dis 2007;66:1137-42.

[75] Acheson ED, Bachrach CA, Wright FM. Some comments on the relationship of the distribution of multiple sclerosis to latitude, solar radiation, and other variables. Acta Psychiatr Scand 1960;35:132-47.

[76] Goldberg P. Multiple sclerosis: vitamin D and calcium as environmental determinants of prevalence (a viewpoint), part I: sunlight, dietary factors and epidemiology. Int J Environ Stud 1974;6:19-27.

[77] Goodin DS. The epidemiology of multiple sclerosis: insights to disease pathogenesis. Handb Clin Neurol 2014;122:231-66.

[78] Hayes CE, Nashold FE, Spach KM, Pedersen LB. The immunological functions of the vitamin D endocrine system. Cell Mol Biol 2003;49:277-300.

[79] Lemire JM, Archer DC. 1,25 Dihydroxyvitamin D3 prevents the in vivo induction of murine experimental autoimmune encephalomyelitis. J Clin Invest 1991;87: 1103-7.

[80] Cantorna MT, Hayes CE, DeLuca HF. 1,25-Dihydroxyvitamin D3 reversibly blocks the progression of relapsing encephalomyelitis, a model of multiple sclerosis. Proc Natl Acad Sci U S A 1996;93:7861-4.

[81] Simpson Jr S, Taylor B, Blizzard L, Ponsonby AL, Pittas F, Tremlett H, et al. Higher 25 hydroxyvitamin D is associated with lower relapse risk in multiple sclerosis. Ann Neurol 2010;68:193-203.
[82] Stewart N, Simpson Jr S, van der Mei I, Ponsonby AL, Blizzard L, Dwyer T, et al. Interferon- $\beta$ and serum 25 -hydroxyvitamin $D$ interact to modulate relapse risk in MS. Neurology 2012;79:254-60.

[83] Mowry EM, Waubant E, McCulloch CE, Okuda DT, Evangelista AA, Lincoln RR, et al. Vitamin D status predicts new brain magnetic resonance imaging activity in multiple sclerosis. Ann Neurol 2012;72:234-40.

[84] Ascherio A, Munger KL, White R, Köchert K, Simon KC, Polman CH, et al. Vitamin D as an early predictor of multiple sclerosis activity and progression. JAMA Neurol 2014;71:306-14

[85] Munger KL, Levin LI, Hollis BW, Howard NS, Ascherio A. Serum 25-hydroxyvitamin D levels and risk of multiple sclerosis. JAMA 2006;296:2832-8.

[86] Browne RW, Weinstock-Guttman B, Zivadinov R, Horakova D, Bodziak ML Tamaño-Blanco M, et al. Serum lipoprotein composition and vitamin D metabolite levels in clinically isolated syndromes: results from a multi-center study. J Steroid Biochem Mol Biol 2014;143:424-33.

[87] Sadiq S. In: Rowland L, editor. Multiple sclerosis. Merritt's NeurologyPhiladelphia: Lippincott Williams and Wilkins; 2005. p. 941-63.

[88] Poloni G, Minagar A, Haacke EM, Zivadinov R. Recent developments in imaging of multiple sclerosis. Neurologist 2011;17:185-204.

[89] Waubant E. Biomarkers indicative of blood-brain barrier disruption in multiple sclerosis. Dis Markers 2006;22:235-44.

[90] Marchi N, Rasmussen P, Kapural M, Fazio V, Kight K, Mayberg MR, et al. Peripheral markers of brain damage and blood-brain barrier dysfunction. Restor Neurol Neurosci 2003;21:109-21.

[91] Missler U, Wandinger KP, Wiesmann M, Kaps M, Wessel K. Acute exacerbation of multiple sclerosis increases plasma levels of S-100 protein. Acta Neurol Scand 1997; $96: 142-4$

[92] Minagar A, Clemente MG, Kelley RE, Alexander JS, Fasano A. Zonulin in multiple sclerosis: relation to subtypes of disease. Neurology 2004;62:A486.

[93] Giovannoni G, Lai M, Thorpe J, Kidd D, Chamoun V, Thompson AJ, et al. Longitudinal study of soluble adhesion molecules in multiple sclerosis: correlation with gadolinium enhanced magnetic resonance imaging. Neurology 1997;48:1557-65.

[94] Rieckmann P, Altenhofen B, Riegel A, Baudewig J, Felgenhauer K. Soluble adhesion molecules (sVCAM-1 and sICAM-1) in cerebrospinal fluid and serum correlate with MRI activity in multiple sclerosis. Ann Neurol 1997;41:326-33.

[95] Kuenz B, Lutterotti A, Khalil M, Ehling R, Gneiss C, Deisenhammer F, et al. Plasma levels of soluble adhesion molecules sPECAM-1, sP-selectin and sE-selectin are associated with relapsing-remitting disease course of multiple sclerosis. J Neuroimmunol 2005;167:143-9.

[96] Losy J, Niezgoda A, Wender M. Increased serum levels of soluble PECAM-1 in multiple sclerosis patients with brain gadolinium-enhancing lesions. J Neuroimmunol 1999;99:169-72.

[97] Rudick RA, Rosahoff RM. Cytokine secretion by multiple sclerosis monocytes. Arch Neurol 1992;49:265-70.

[98] Alatab S, Maghbooli Z, Hossein-Nezhad A, Khosrofar M, Mokhtari F. Cytokine profile, Foxp3 and nuclear factor-kB ligand levels in multiple sclerosis subtypes. Minerva Med 2011;102:461-8.

[99] Bar-Or A, Fawaz L, Fan B, Darlington PJ, Rieger A, Ghorayeb C, et al. Abnormal B-cell cytokine responses a trigger of T-cell-mediated disease in MS? Ann Neurol 2010; 67:452-61.

[100] De Jager PL, Rossin E, Pyne S. Cytometric profiling in multiple sclerosis uncovers patient population structure and a reduction of CD8 low cells. Brain 2008;131: 1701-11.

[101] Dhib-Jalbut S. Pathogenesis of myelin/oligodendrocyte damage in multiple sclerosis. Neurology 2007;68:S13-21.

[102] Korn T, Bettelli E, Oukka M, Kuchroo VK. IL-17 and Th17 cells. Annu Rev Immunol 2009;27:485-517.

[103] Axtell RC, de Jong BA, Boniface K, van der Voort LF, Bhat R, De Sarno P, et al. T helper type 1 and 17 cells determine efficacy of interferon-beta in multiple sclerosis and experimental encephalomyelitis. Nat Med 2010;16:406-12.

[104] Hartung HP, Steinman L, Goodin DS, Comi G, Cook S, Filippi M, et al. Interleukin 17F level and interferon $\beta$ response in patients with multiple sclerosis. JAMA Neurol 2013;70:1017-21.

[105] Graber JJ, Dhib-Jalbut S. Protective autoimmunity in neurologic disease. Pharmacol Ther 2009:121:147-59.

[106] Correale J, Villa A. Role of $\mathrm{CD}^{+} \mathrm{CD}^{2} 5^{+} \mathrm{FoxP} 3^{+}$regulatory T cells in multiple sclerosis. Ann Neurol 2010;67:625-38.

[107] Chen YC, Yang X, Miao L, Liu ZG, Li W, Zhao ZX, et al. Serum level of interleukin-6 in Chinese patients with multiple sclerosis. J Neuroimmunol 2012;249:109-11.

[108] Wang H, Wang K, Wang C, Zhong X, Qiu W, Hu X. Increased plasma levels of pentraxin 3 in patients with multiple sclerosis and neuromyelitis optica. Mult Scler 2013;19:926-31.

[109] Waubant E, Goodkin DE, Gee L, Bacchetti P, Sloan R, Stewart T, et al. Serum MMP-9 and TIMP-1 levels are related to MRI activity in relapsing multiple sclerosis. Neurology 1999;53:1397-401.

[110] Qin C, Baba O, Butler WT. Post-translational modifications of sibling proteins and their roles in osteogenesis and dentinogenesis. Crit Rev Oral Biol Med 2004;15: 126-36.

[111] Mazzali M, Kipari T, Ophascharoensuk V, Wesson JA, Johnson R, Hughes J. Osteopontin-a molecule for all seasons. QJM 2002;95:3-13.

[112] Chabas D, Baranzini SE, Mitchell D, Bernard CC, Rittling SR, Denhardt DT, et al. The influence of the proinflammatory cytokine, osteopontin, on autoimmune demyelinating disease. Science 2001;294:1731-5.

[113] Hur EM, Youssef S, Haws ME, Zhang SY, Sobel RA, Steinman L. Osteopontin-induced relapse and progression of autoimmune brain disease through enhanced survival of activated T cells. Nat Immunol 2007;8:74-83. 
[114] Murugaiyan G, Mittal A, Weiner HL. Increased osteopontin expression in dendritic cells amplifies IL-17 production by $\mathrm{CD}^{+}{ }^{+} \mathrm{T}$ cells in experimental autoimmune encephalomyelitis and in multiple sclerosis. J Immunol 2008;181:7480-8.

[115] Comabella M, Pericot I, Goertsches R, Nos C, Castillo M, Blas Navarro J, et al. Plasma osteopontin levels in multiple sclerosis. J Neuroimmunol 2005;158:231-9.

[116] Vogt MH, Lopatinskaya L, Smits M, Polman CH, Nagelkerken L, et al. Elevated osteopontin levels in active relapsing-remitting multiple sclerosis. Ann Neurol 2003;53: 819-22.

[117] Vogt MH, Floris S, Killestein J, Knol DL, Smits M, Barkhof F, et al. Osteopontin levels and increased disease activity in relapsing-remitting multiple sclerosis patients. J Neuroimmunol 2004;155:155-60.

[118] Romo-Tena J, Gómez-Martín D, Alcocer-Varela J. CTLA-4 and autoimmunity: new insights into the dual regulator of tolerance. Autoimmun Rev 2013;12:1171-6.

[119] Oliveira EM, Bar-Or A, Waliszewska AI, Cai G, Anderson DE, Krieger JI, et al. CTLA-4 dysregulation in the activation of myelin basic protein reactive $T$ cells may distinguish patients with multiple sclerosis from healthy controls. J Autoimmun 2003; 20:71-81.

[120] Lovett-Racke AE, Trotter JL, Lauber J, Perrin PJ, June CH, Racke MK. Decreased dependence of myelin basic protein-reactive T cells on CD28 - mediated costimulation in multiple sclerosis patients. A marker of activated/memory $\mathrm{T}$ cells. J Clin Invest 1998;101:725-30.

[121] Markovic-Plese S, Cortese I, Wandinger KP, McFarland HF, Martin R. CD4 ${ }^{+} \mathrm{CD}_{2} 8^{-}$ costimulation-independent T cells in multiple sclerosis. J Clin Invest 2001;108: 1185-94.

[122] Zang X, Loke P, Kim J, Murphy K, Waitz R, Allison JP. B7x: a widely expressed B7 family member that inhibits T cell activation. Proc Natl Acad Sci U S A 2003;100: 10388-92.

[123] Liang SC, Latchman YE, Buhlmann JE, Tomczak MF, Horwitz BH, Freeman GJ, et al. Regulation of PD-1, PD-L1, and PD-L2 expression during normal and autoimmune responses. Eur J Immunol 2003;33:2706-16.

[124] Gianchecchi E, Delfino DV, Fierabracci A. Recent insights into the role of the PD-1/ PD-L1 pathway in immunological tolerance and autoimmunity. Autoimmun Rev 2013:12:1091-100.

[125] Salama AD, Chitnis T, Imitola J, Ansari MJ, Akiba H, Tushima F, et al. Critical role of the programmed death-1 (PD-1) pathway in regulation of experimental autoimmune encephalomyelitis. J Exp Med 2003;198:71-8.

[126] Trabattoni D, Saresella M, Pacei M, Marventano I, Mendozzi L, Rovaris M, et al. Costimulatory pathways in multiple sclerosis: distinctive expression of PD- 1 and PDL-1 in patients with different patterns of disease. J Immunol 2009;183:4984-93.

[127] Kwon B, Lee HW, Kwon BS. New insights into the role of 4-1BB in immune responses: beyond $\mathrm{CD}^{+}{ }^{+} \mathrm{T}$ cells. Trends Immunol 2002;23:378-80.

[128] Schwarz H, Valbracht J, Tuckwell J, von Kempis J, Lotz M. ILA, the human 4-1BB homologue, is inducible in lymphoid and other cell lineages. Blood 1995;85: 1043-52.

[129] Myers LM, Vella AT. Interfacing T-cell effector and regulatory function through CD137 (4-1BB) costimulation. Trends Immunol 2005;26:440-6.

[130] Liu GZ, Gomes AC, Putheti P, Karrenbauer V, Kostulas K, Press R, et al. Increased soluble 4-1BB ligand (4-1BBL) levels in peripheral blood of patients with multiple sclerosis. Scand J Immunol 2006;64:412-9.

[131] Zipp F, Martin R, Lichtenfels R, Roth W, Dichgans J, Krammer PH, et al. Human autoreactive and foreign antigen-specific T cells resist apoptosis induced by soluble recombinant CD95 ligand. J Immunol 1997;159:2108-15.

[132] D'Souza SD, Bonetti B, Balasingam V, Cashman NR, Barker PA, Troutt AB, et al. Multiple sclerosis: fas signaling in oligodendrocyte death. J Exp Med 1996;184: 2361-70.

[133] Huang W-X, Huang MP, Gomes MA, Hillert J. Apoptosis mediators FasL and TRAIL are upregulated in peripheral blood mononuclear cells in MS. Neurology 2000; 55:928-34.

[134] Inoue A, Koh CS, Sakai T, Yamazaki M, Yanagisawa N, Usuku K, et al. Detection of soluble form of the Fas molecule in patients with multiple sclerosis and human Tlymphotropic virus type I-associated myelopathy. J Neuroimmunol 1997;75:141-6.

[135] Moreno M, Sáenz-Cuesta M, Castilló J, Cantó E, Negrotto L, Vidal-Jordana A. Circulating levels of soluble apoptosis-related molecules in patients with multiple sclerosis. J Neuroimmunol 2013;263:152-4.

[136] Ciusani E, Frigerio S, Gelati M, Corsini E, Dufour A, Nespolo A, et al. Soluble Fas (Apo-1) levels in cerebrospinal fluid of multiple sclerosis patients. J Neuroimmunol 1998;82:5-12.

[137] Comi C, Leone M, Bonissoni S, DeFranco S, Bottarel F, Mezzatesta C. Defective T cell Fas function in patients with multiple sclerosis. Neurology 2000;55:921-7.

[138] Lopatinskaya L, Van Boxel-Dezaire AH, Barkhof F, Polman CH, Lucas CJ, Nagelkerken L. The development of clinical activity in relapsing-remitting MS is associated with a decrease of FasL mRNA and an increase of Fas mRNA in peripheral blood. J Neuroimmunol 2003;128:123-31.

[139] Sharief MK, Semra YK. Heightened expression of survivin in activated T lymphocytes from patients with multiple sclerosis. J Neuroimmunol 2001;119:358-64.

[140] Sharief M, Noori M, Douglas M, Noori M. Upregulated survivin expression in activated T lymphocytes correlates with disease activity in multiple sclerosis. Eur J Neurol 2002:9:503-10.

[141] Sharief M, Semra Y. Down-regulation of survivin expression in T lymphocytes after interferon beta-1a treatment in patients with multiple sclerosis. Eur J Neurol 2002; 59:1115-21.

[142] Varga Z, Hajdu P, Panyi G. Ion channels in T lymphocytes: an update on facts, mechanisms and therapeutic targeting in autoimmune diseases. Immunol Lett 2010; 130:19-25.

[143] Bittner S, Bobak N, Herrmann AM, Gobel K, Meuth P, Hohn KG, et al. Upregulation of K2P5.1 potassium channels in multiple sclerosis. Ann Neurol 2010;68:58-69.
[144] Kvistad S, Myhr KM, Holmøy T, Bakke S, Beiske AG, Bjerve KS, et al. Antibodies to Epstein-Barr virus and MRI disease activity in multiple sclerosis. Mult Scler 2014; 20:1833-40.

[145] Burger D, Schock S, Thompson CS, Montezano AC, Hakim AM, Touyz RM. Microparticles: biomarkers and beyond. Clin Sci (Lond) 2013;124:423-41.

[146] Morel O, Jesel L, Freyssinet J-M, Toti F. Cellular mechanisms underlying the formation of circulating microparticles. Arterioscler Thromb Vasc Biol 2011;31: $15-26$.

[147] Cocucci E, Rocchetti G, Meldolesi J. Shedding microvesicles, artefact no more. Trends Cell Biol 2009;19:43-5.

[148] Barteneva NS, Fasler-Kan E, Bernimoulin M, Stern JN, Ponomarev ED, Duckett L, et al. Circulating microparticles: square the circle. BMC Cell Biol 2013;14:23.

[149] Distler JHW, Pisetsky DS, Huber LC, Kalden JR, Gay S, Distler O. Microparticles as regulators of inflammation: novel players of cellular crosstalk in the rheumatic diseases. Arthritis Rheum 2005;52:3337-48.

[150] Markiewicz M, Richard E, Marks N, Ludwicka-Bradley A. Impact of endothelia microparticles on coagulation, inflammation, and angiogenesis in age-related vascular diseases. J Aging Res 2013;2013:734509.

[151] Muralidharan-Chari V, Clancy JW, Sedgwick A, D'Souza-Schorey C. Microvesicles: mediators of extracellular communication during cancer progression. J Cell Sci 2010;123:1603-11.

[152] Buzas EI, György B, Nagy G, Falus A, Gay S. Emerging role of extracellular vesicles in inflammatory diseases. Nat Rev Rheumatol 2014;10:356-64.

[153] Norling LV, Dalli J. Microparticles are novel effectors of immunity. Curr Opin Pharmacol 2013;13:570-5.

[154] Marzesco AM, Janich P, Wilsch-Bräuninger M, Dubreuil V, Langenfeld K, Corbeil D, et al. Release of extracellular membrane particles carrying the stem cell marker prominin-1 (CD133) from neural progenitors and other epithelial cells. J Cell Sci 2005:118:2849-58.

[155] Verderio C, Muzio L, Turola E, Bergami A, Novellino L, Ruffini F, et al. Myeloid microvesicles are a marker and therapeutic target for neuroinflammation. Ann Neurol 2012;72:610-24

[156] Lai CP, Breakefield XO. Role of exosomes/microvesicles in the nervous system and use in emerging therapies. Front Physiol 2012;3:228.

[157] Colombo E, Borgiani B, Verderio C, Furlan R. Microvesicles: novel biomarkers for neurological disorders. Front Physiol 2012;3:63.

[158] Bianco F, Pravettoni E, Colombo A, Schenk U, Möller T, Matteoli M, et al. Astrocytederived ATP induces vesicle shedding and IL-1 beta release from microglia. J Immunol 2005; 174:7268-77.

[159] Horstman LL, Jy W, Minagar A, Bidot C], Jimenez JJ, Alexander JS, et al. Cell-derived microparticles and exosomes in neuroinflammatory disorders. Int Rev Neurobiol 2007;79:227-68.

[160] Sáenz-Cuesta M, Osorio-Querejeta I, Otaegui D. Extracellular vesicles in multiple sclerosis: what are they telling us? Front Cell Neurosci 2014;8:100.

[161] Minagar A, Long A, Ma T, Jackson TH, Kelley RE, Ostanin DV, et al. Interferon (IFN)beta 1a and IFN-beta 1b block IFN-gamma-induced disintegration of endothelial junction integrity and barrier. Endothelium 2003;10:299-307.

[162] Minagar A, Jy W, Jimenez JJ, Sheremata WA, Mauro LM, Mao WW, et al. Elevated plasma endothelial microparticles in multiple sclerosis. Neurology 2001;56: 1319-24.

[163] Minagar A, Maghzi AH, McGee JC, Alexander JS. Emerging roles of endothelial cells in multiple sclerosis pathophysiology and therapy. Neurol Res 2012;34:738-45.

[164] Jimenez J, Jy W, Mauro LM, Horstman LL, Ahn ER, Ahn YS, et al. Elevated endothelial microparticle-monocyte complexes induced by multiple sclerosis plasma and the inhibitory effects of interferon-beta $1 \mathrm{~b}$ on release of endothelial microparticles formation and transendothelial migration of monocyte-endothelial microparticle complexes. Mult Scler 2005;11:310-5.

[165] Sáenz-Cuesta M, Irizar H, Castillo-Triviño T, Muñoz-Culla M, Osorio-Querejeta I, Prada A, et al. Circulating microparticles reflect treatment effects and clinical status in multiple sclerosis. Biomark Med 2014;8:653-61.

[166] Turiák L, Misják P, Szabó TG, Aradi B, Pálóczi K, Ozohanics O, et al. Proteomic characterization of thymocyte-derived microvesicles and apoptotic bodies in BALB/C mice. J Proteomics 2011;74:2025-33.

[167] Momen-Heravi F, Balaj L, Alian S, Mantel PY, Halleck AE, Trachtenberg AJ, et al. Current methods for the isolation of extracellular vesicles. Biol Chem 2013;394:1253-62

[168] Qu Z, Li W, Fu B. MicroRNAs in autoimmune diseases. Biomed Res Int 2014;2014: 527895.

[169] Zhu S, Pan W, Qian Y. MicroRNA in immunity and autoimmunity. J Mol Med (Berl) 2013;91:1039-50.

[170] Lewis BP, Shih IH, Jones-Rhoades MW, Bartel DP, Burge CB. Prediction of mammalian microRNA targets. Cell 2003;115:787-98.

[171] Eulalio A, Huntzinger E, Izaurralde E. Getting to the root of miRNA-mediated gene silencing. Cell 2008;132:9-14

[172] Guo H, Ingolia NT, Weissman JS, Bartel DP. Mammalian microRNAs predominantly act to decrease target mRNA levels. Nature 2010;466:835-40.

[173] Esteller M. Non-coding RNAs in human disease. Nat Rev Genet 2011;12:861-74.

[174] Otaegui D, Baranzini SE, Armañanzas R, Calvo B, Muñoz-Culla M, Khankhanian P. et al. Differential micro RNA expression in PBMC from multiple sclerosis patients. PLoS One 2009;4:e6309.

[175] Fenoglio C, Cantoni C, De Riz M, Ridolfi E, Cortini F, Serpente M, et al. Expression and genetic analysis of miRNAs involved in $\mathrm{CD}^{+}{ }^{+}$cell activation in patients with multiple sclerosis. Neurosci Lett 2011:504:9-12.

[176] Martinelli-Boneschi F, Fenoglio C, Brambilla P, Sorosina M, Giacalone G, Esposito F, et al. MicroRNA and mRNA expression profile screening in multiple sclerosis patients to unravel novel pathogenic steps and identify potential biomarkers. Neurosci Lett 2012;508:4-8. 
[177] Keller A, Leidinger P, Lange J, Borries A, Schroers H, Scheffler M, et al. Multiple sclerosis: microRNA expression profiles accurately differentiate patients with relapsing-remitting disease from healthy controls. PLoS One 2009;4:e7440.

[178] Cox MB, Cairns MJ, Gandhi KS, Carroll AP, Moscovis S, Stewart GJ, et al. MicroRNAs miR-17 and miR-20a inhibit T cell activation genes and are under-expressed in MS whole blood. PLoS One 2010;5:e12132.

[179] Junker A, Krumbholz M, Eisele S, Mohan H, Augstein F, Bittner R, et al. MicroRNA profiling of multiple sclerosis lesions identifies modulators of the regulatory protein CD47. Brain 2009;132:3342-52.

[180] Littman DR, Rudensky AY. Th17 and regulatory T cells in mediating and restraining inflammation. Cell 2010;140:845-58.

[181] Zahednasab H, Balood M. The role of miR-326 and miR-26a in MS disease activity. Gene 2014;548:158

[182] Du C, Liu C, Kang J, Zhao G, Ye Z, Huang S, et al. MicroRNA-326 regulates Th-17 differentiation and is associated with the pathogenesis of multiple sclerosis. Nat Immunol 2009;10:1252-9.

[183] Zhang J, Cheng Y, Cui W, Li M, Li B, Guo L. MicroRNA-155 modulates Th1 and Th17 cell differentiation and is associated with multiple sclerosis and experimental autoimmune encephalomyelitis. J Neuroimmunol 2014;266:56-63.

[184] Hanke M, Hoefig K, Merz H, Feller AC, Kausch I, Jocham D, et al. A robust methodology to study urine microRNA as tumor marker: microRNA-126 and microRNA182 are related to urinary bladder cancer. Urol Oncol 2010;28:655-61.

[185] Park NJ, Zhou H, Elashoff D, Henson BS, Kastratovic DA, Abemayor E, et al. Salivary microRNA: discovery, characterization, and clinical utility for oral cancer detection. Clin Cancer Res 2009;15:5473-7.

[186] Mitchell PS, Parkin RK, Kroh EM, Fritz BR, Wyman SK, Pogosova-Agadjanyan EL et al. Circulating microRNAs as stable blood-based markers for cancer detection. Proc Natl Acad Sci U S A 2008;105:10513-8.

[187] Redell JB, Moore AN, Ward III NH, Hergenroeder GW, Dash PK. Human traumatic brain injury alters plasma microRNA levels. J Neurotrauma 2010;27:2147-56

[188] Kacperska MJ, Jastrzebski K, Tomasik B, Walenczak J, Konarska-Krol M, Glabinski A Selected extracellular microRNA as potential biomarkers of multiple sclerosis activity-preliminary study. J Mol Neurosci 2015;56:154-63.

[189] Lindberg RL, Hoffmann F, Mehling M, Kuhle J, Kappos L. Altered expression of miR17-5p in $\mathrm{CD}^{+}{ }^{+}$lymphocytes of relapsing-remitting multiple sclerosis patients. Eur J Immunol 2010;40:888-98.

[190] Xiao C, Srinivasan L, Calado DP, Patterson HC, Zhang B, Wang J, et al. Lymphoproliferative disease and autoimmunity in mice with increased miR-17-92 expression in lymphocytes. Nat Immunol 2008;9:405-14.

[191] De Santis G, Ferracin M, Biondani A, Caniatti L, Tola MR, Castellazzi M, et al. Altered miRNA expression in T regulatory cells in course of multiple sclerosis. J Neuroimmunol 2010;226:165-71.

[192] Petrocca F, Vecchione A, Croce CM. Emerging role of miR-106b-25/miR-17-92 clusters in the control of transforming growth factor beta signaling. Cancer Res 2008;68:8191-4.

[193] Confavreux C, Vukusic S, Adeleine P. Early clinical predictors and progression of irreversible disability in multiple sclerosis: an amnesic process. Brain 2003;126: $770-82$.

[194] Leray E, Yaouanq J, Le Page E, Coustans M, Laplaud D, Oger J, et al. Evidence for a two-stage disability progression in multiple sclerosis. Brain 2010;133:1900-13.

[195] Rovaris M, Confavreux C, Furlan R, Kappos L, Comi G, Filippi M. Secondary progressive multiple sclerosis: current knowledge and future challenges. Lancet Neurol 2006;5: 343-54.

[196] De Jager PL, Hafler DA. New therapeutic approaches for multiple sclerosis. Annu Rev Med 2007;58:417-32.

[197] Lassmann H, van Horssen J, Mahad D. Progressive multiple sclerosis: pathology and pathogenesis. Nat Rev Neurol 2012;8:647-56.

[198] Lublin FD, Reingold SC, Cohen JA, Cutter GR, Sørensen PS, Thompson AJ, et al Defining the clinical course of multiple sclerosis: the 2013 revisions. Neurology 2014;83:278-86.

[199] Losseff NA, Webb SL, O'Riordan JI, Page R, Wang L, Barker GJ, et al. Spinal cord atrophy and disability in multiple sclerosis. A new reproducible and sensitive MRI method with potential to monitor disease progression. Brain 1996;119:701-8.

[200] Losseff NA, Wang L, Lai HM, Yoo DS, Gawne-Cain ML, McDonald WI, et al. Progressive cerebral atrophy in multiple sclerosis: a serial MRI study. Brain 1996;119: 2009-19.

[201] Ge Y, Grossman RI, Udupa JK, Babb JS, Nyúl LG, Kolson DL. Brain atrophy in relapsing-remitting multiple sclerosis: fractional volumetric analysis of gray matter and white matter. Radiology 2001;220:606-10.

[202] Shaw G, Yang C, Ellis R, Anderson K, Parker Mickle J, Scheff S, et al. Hyperphosphorylated neurofilament NF-H is a serum biomarker of axonal injury. Biochem Biophys Res Commun 2005;336:1268-77.

[203] Siman R, Toraskar N, Dang A, McNeil E, McGarvey M, Plaum J, et al. A panel of neuron enriched proteins as markers for traumatic brain injury in humans. Neurotrauma 2009;26:1867-77.

[204] Fabriek BO, Zwemmer JN, Teunissen CE, Dijkstra CD, Polman CH, Laman JD, et al. In vivo detection of myelin proteins in cervical lymph nodes of MS patients using ultrasound-guided fine-needle aspiration cytology. J Neuroimmunol 2005: $161190-4$.

[205] Lily O, Palace J, Vincent A. Serum autoantibodies to cell surface determinants in multiple sclerosis: a flow cytometric study. Brain 2004;127:269-79.

[206] Gresle MM, Shaw G, Jarrott B, Alexandrou EN, Friedhuber A, Kilpatrick TJ, et al. Validation of a novel biomarker for acute axonal injury in experimental autoimmune encephalomyelitis. J Neurosci Res 2008;86:3548-55.

[207] Teunissen CE, Dijkstra C, Polman C. Biological markers in CSF and blood for axonal degeneration in multiple sclerosis. Lancet Neurol 2005;4:32-41.
[208] Julien JP, Mushynski WE. Neurofilaments in health and disease. Prog Nucleic Acid Res Mol Biol 1998;61:1-23.

[209] Lycke JN, Karlsson JE, Andersen O, Rosengren LE. Neurofilament protein in cerebrospinal fluid: a potential marker of activity in multiple sclerosis. J Neurol Neurosurg Psychiatry 1998;64:402-4.

[210] Gresle MM, Liu Y, Dagley LF, Haartsen J, Pearson F, Purcell AW, et al. Serum phosphorylated neurofilament-heavy chain levels in multiple sclerosis patients. J Neurol Neurosurg Psychiatry 2014;85:1209-13.

[211] Ehling R, Lutterotti A, Wanschitz J, Khalil M, Gneiss C, Deisenhammer F, et al. Increased frequencies of serum antibodies to neurofilament light in patients with primary chronic progressive multiple sclerosis. Mult Scler 2004;10:601-6.

[212] Silber E, Semra YK, Gregson NA, Sharief MK. Patients with progressive multiple sclerosis have elevated antibodies to neurofilament subunit. Neurology 2002;8: 1372-81.

[213] Kamath K, Oroudjev E, Jordan MA. Determination of microtubule dynamic instability in living cells. Methods Cell Biol 2010;97:1-14.

[214] Semra YK, Seidi OA, Sharief MK. Heightened intrathecal release of axonal cytoskeletal proteins in multiple sclerosis is associated with progressive disease and clinical disability. J Neuroimmunol 2002;122:132-9.

[215] Fialová L, Bartos A, Soukupová J, Svarcová J, Ridzon P, Malbohan I. Synergy of serum and cerebrospinal fluid antibodies against axonal cytoskeletal proteins in patients with different neurological diseases. Folia Biol 2009;55:23-6.

[216] Lolli F, Mulinacci B, Carotenuto A, Bonetti B, Sabatino G, Mazzanti B, et al. An Nglucosylated peptide detecting disease-specific autoantibodies, biomarkers of multiple sclerosis. Proc Natl Acad Sci U S A 2005;102:10273-8.

[217] Quintana FJ, Farez MF, Viglietta V, Iglesias AH, Merbl Y, Izquierdo G, et al. Antigen microarrays identify unique serum autoantibody signatures in clinical and pathologic subtypes of multiple sclerosis. Proc Natl Acad Sci U S A 2008;105:18889-94.

[218] Gao YL, Brosnan CF, Raine CS. Experimental autoimmune encephalomyelitis. Qualitative and semiquantitative differences in heat shock protein 60 expression in the central nervous system. J Immunol 1995;154:3548-56.

[219] Eikelenboom MJ, Uitdehaag BM, Petzold A. Blood and CSF biomarker dynamics in multiple sclerosis: implications for data interpretation. Mult Scler Int 2011;2011: 823176.

[220] Lopatinskaya L, Zwemmer J, Uitdehaag B, Lucas K, Polman C, Nagelkerken L. Mediators of apoptosis Fas and FasL predict disability progression in multiple sclerosis over a period of 10 years. Mult Scler 2006;12:704-9.

[221] Kallaur AP, Oliveira SR, Colado Simão AN, Delicato de Almeida ER, Kaminami Morimoto $\mathrm{H}$, Lopes J, et al. Cytokine profile in relapsing-remitting multiple sclerosis patients and the association between progression and activity of the disease. Mol Med Rep 2013;7:1010-20.

[222] Fissolo N, Cantó E, Vidal-Jordana A, Castilló J, Montalban X, Comabella M. Levels of soluble TNF-RII are increased in serum of patients with primary progressive multiple sclerosis. J Neuroimmunol 2014;271:56-9.

[223] Amorini AM, Nociti V, Petzold A, Gasperini C, Quartuccio E, Lazzarino G, et al. Serum lactate as a novel potential biomarker in multiple sclerosis. Biochim Biophys Acta 1842:2014:1137-43.

[224] Fonalledas Perelló MA, Politi JV, Dallo Lizarraga MA, Cardona RS. The cerebrospinal fluid lactate is decreased in early stages of multiple sclerosis. P R Health Sci J 2008; 27:171-4.

[225] Gandhi R, Healy B, Gholipour T, Egorova S, Musallam A, Hussain MS, et al. Circulating microRNAs as biomarkers for disease staging in multiple sclerosis. Ann Neurol 2013;73:729-40.

[226] Pawate S, Bagnato F. Newer agents in the treatment of multiple sclerosis. Neurologist 2015;19:104-17.

[227] Bertolotto A, Gilli F. Interferon-beta responders and non-responders. A biological approach. Neurol Sci 2008;29:S216-7.

[228] Yong V, Chabot S, Stuve O, Williams G. Interferon beta in the treatment of multiple sclerosis: mechanisms of action. Neurology 1998;51:682-9.

[229] Yong V. Differential mechanisms of action of interferon-beta and glatiramer acetate in MS. Neurology 2002;59:802-8.

[230] Sharief M, Semra Y, Seidi O, Zoukos Y. Interferon-beta therapy downregulates the anti-apoptosis protein FLIP in T cells from patients with multiple sclerosis. J Neuroimmunol 2001;120:199-207.

[231] Leppert D, Waubant E, Burk M, Oksenberg J, Hauser SL. Interferon beta-1b inhibits gelatinase secretion and in vitro migration of human T cells: a possible mechanism for treatment efficacy in multiple sclerosis. Ann Neurol 1996;40:846-52.

[232] Vartanian TK, Zamvil SS, Fox E, Sorensen PS. Neutralizing antibodies to diseasemodifying agents in the treatment of multiple sclerosis. Neurology 2004;63:S42-9.

[233] Creeke PI, Farrell RA. Clinical testing for neutralizing antibodies to interferon- $\beta$ in multiple sclerosis. Ther Adv Neurol Disord 2013:6:3-17.

[234] Haller O, Kochs G. Interferon-induced mx proteins: dynamin-like GTPases with antiviral activity. Traffic 2002;3:710-7

[235] Deisenhammer F, Reindl M, Harvey J, Gasse T, Dilitz E, Berger T. Bioavailability of interferon beta 1b in MS patients with and without neutralizing antibodies. Neurology 1999;52:1239-43.

[236] Pachner AR, Bertolotto A, Deisenhammer F. Measurement of MxA mRNA or protein as a biomarker of IFN beta bioactivity: detection of antibody-mediated decreased bioactivity (ADB). Neurology 2003;61:S24-6.

[237] Bertolotto A, Gilli F, Sala A, Capobianco M, Malucchi S, Milano E, et al. Persistent neutralizing antibodies abolish the interferon beta bioavailability in MS patients. Neurology 2003;60:634-9.

[238] Bertolotto A, Gilli F, Sala A, Audano L, Castello A, Magliola U, et al. Evaluation of bioavailability of three types of IFNbeta in multiple sclerosis patients by a new quantitative-competitive-PCR method for MxA quantification. J Immunol Methods 2001;256:141-52. 
[239] Pachner A, Narayan K, Price N, Hurd M, Dail D. MxA gene expression analysis as an interferon-beta bioactivity measurement in patients with multiple sclerosis and the identification of antibody-mediated decreased bioactivity. Mol Diagn 2003;7:17-25.

[240] Pachner AR, Dail D, Pak E, Narayan K. The importance of measuring IFNbeta bioactivity: monitoring in MS patients and the effect of anti-IFNbeta antibodies. J Neuroimmunol 2005;166:180-8.

[241] Gilli F, Bertolotto A, Sala A, Hoffmann F, Capobianco M, Malucchi S, et al. Neutralizing antibodies against IFN-beta in multiple sclerosis: antagonization of IFN-beta mediated suppression of MMPs. Brain 2004;127:259-68.

[242] Malucchi S, Gilli F, Caldano M, Marnetto F, Valentino P, Granieri L, et al. Predictive markers for response to interferon therapy in patients with multiple sclerosis. Neurology 2008;70:1119-27.

[243] Kayagaki N, Yamaguchi N, Nakayama M, Eto H, Okumura K, Yagita H. Type I interferons (IFNs) regulate tumor necrosis factor-related apoptosis-inducing ligand (TRAIL) expression on human T cells: a novel mechanism for the antitumor effects of type I IFNs. J Exp Med 1999;189:1451-60.

[244] Arbour N, Rastikerdar E, McCrea E, Lapierre Y, Dörr J, Bar-Or A, et al. Upregulation of TRAIL expression on human T lymphocytes by interferon beta and glatiramer acetate. Mult Scler 2005;11:652-7.

[245] Sato K, Hida S, Takayanagi H, Yokochi T, Kayagaki N, Takeda K, et al. Antiviral response by natural killer cells through TRAIL gene induction by IFN-alpha/beta. Eur J Immunol 2001;31:3138-46.

[246] Zula JA, Green HC, Ransohoff RM, Rudick RA, Stark GR, van Boxel-Dezaire AH. The role of cell type-specific responses in IFN-beta therapy of multiple sclerosis. Proc Natl Acad Sci U S A 2011;108:19689-94.

[247] Wandinger KP, Lünemann JD, Wengert O, Bellmann-Strobl J, Aktas O, Weber A, et al. TNF-related apoptosis inducing ligand (TRAIL) as a potential response marker for interferon-beta treatment in multiple sclerosis. Lancet 2003;361:2036-43.

[248] Aktas O, Schulze-Topphoff U, Zipp F. The role of TRAIL/TRAIL receptors in central nervous system pathology. Front Biosci 2007;12:2912-21.

[249] Buttmann M, Merzyn C, Hofstetter HH, Rieckmann P. TRAIL, CXCL10 and CCL2 plasma levels during long-term interferon-beta treatment of patients with multiple sclerosis correlate with flu-like adverse effects but do not predict therapeutic response. J Neuroimmunol 2007;190:170-6.

[250] Comabella M, Río J, Espejo C, Ruiz de Villa M, Al-Zayat H, Nos C, et al. Changes in matrix metalloproteinases and their inhibitors during interferon-beta treatment in multiple sclerosis. Clin Immunol 2009;130:145-50.

[251] Alexander JS, Harris MK, Wells SR, Mills G, Chalamidas K, Ganta VC, et al. Alterations in serum MMP-8, MMP-9, IL-12 p40 and IL-23 in multiple sclerosis patients treated with interferon-beta1b. Mult Scler 2010;16:801-9.

[252] Stüve O, Dooley NP, Uhm JH, Antel JP, Francis GS, Williams G, et al. Interferon beta$1 \mathrm{~b}$ decreases the migration of $\mathrm{T}$ lymphocytes in vitro: effects on matrix metalloproteinase-9. Ann Neurol 1996;40:853-63.

[253] Nelissen I, Martens E, Van den Steen PE, Proost P, Ronsse I, Opdenakker G. Gelatinase B/matrix metalloproteinase-9 cleaves interferon-beta and is a target for immunotherapy. Brain 2003;126:1371-81.

[254] Nelissen I, Ronsse I, Van Damme J, Opdenakker G. Regulation of gelatinase B in human monocytic and endothelial cells by PECAM1 ligation and its modulation by interferonbeta. J Leukoc Biol 2002;71:89-98.

[255] Galboiz Y, Shapiro S, Lahat N, Rawashdeh H, Miller A. Matrix metalloproteinases and their tissue inhibitors as markers of disease subtype and response to interferon beta therapy in relapsing and secondary-progressive multiple sclerosis patients. Ann Neurol 2001;50:443-51.

[256] Opdenakker G, Van den Steen PE, Van Damme J. Gelatinase B: a tuner and amplifier of immune functions. Trends Immunol 2001;22:571-9.

[257] Lau AS, Hannigan GE, Freedman MH, Williams BR. Regulation of IFN receptor expression in human blood lymphocytes in vitro and during interferon therapy. J Clin Invest 1986;77:1632-8.

[258] Oliver B, Mayorga C, Fernández V, Leyva L, León A, Luque G, et al. Interferon receptor expression in multiple sclerosis patients. J Neuroimmunol 2007;183:225-31.

[259] Gilli F, Valentino P, Caldano M, Granieri L, Capobianco M, Malucchi S, et al. Expression and regulation of IFNalpha/beta receptor in IFNbeta-treated patients with multiple sclerosis. Neurology 2008;71:1940-7.

[260] Comabella M, Lunemann JD, Rio J, Sanchez A, Lopez C, Julia E, et al. A type I interferon signature in monocytes is associated with poor response to interferon-beta in multiple sclerosis. Brain 2009;132:3353-65.

[261] Rudick RA, Rani MR, Xu Y, Lee JC, Na J, Shrock J, et al. Excessive biologic response to IFNbeta is associated with poor treatment response in patients with multiple sclerosis. PLoS One 2011;6:e19262.

[262] Bustamante MF, Nurtdinov RN, Rio J, Montalban X, Comabella M. Baseline gene expression signatures in monocytes from multiple sclerosis patients treated with interferon-beta. PLoS One 2013;8:e60994.

[263] Bustamante MF, Fissolo N, Rio J, Espejo C, Costa C, Mansilla MJ, et al. Implication of the Toll-like receptor 4 pathway in the response to interferon-beta in multiple sclerosis. Ann Neurol 2011:70:634-45.

[264] Bălaşa R, Huţanu A, Bajko Z, Feier C, Pascu I. Does the serum IL-17 titer influence the efficacy of interferon-â treatment in multiple sclerosis patients? Rev Rom Med Lab 2011;19:381-9.

[265] Haak S, Croxford AL, Kreymborg K, Heppner FL, Pouly S, Becher B, et al. IL-17A and IL-17F do not contribute vitally to autoimmune neuro-inflammation in mice. J Clin Invest 2009;119:61-9.
[266] Tao Y, Zhang X, Chopra M, Kim MJ, Buch KR, Kong D, et al. The role of endogenous IFN- $\beta$ in the regulation of Th17 responses in patients with relapsing-remitting multiple sclerosis. J Immunol 2014;192:5610-7.

[267] Waubant E, Gee L, Bacchetti P, Sloan R, Cotleur A, Rudick R, et al. Relationship between serum levels of IL-10, MRI activity and interferon beta-1a therapy in patients with relapsing remitting MS. J Neuroimmunol 2001;112:139-45.

[268] Petereit H, Pukrop R, Fazekas F, Bamborschke SU, Ropele S, Kolmel HW, et al. Low interleukin-10 production is associated with higher disability and MRI lesion load in secondary progressive multiple sclerosis. J Neurol Sci 2003;206:209-14.

[269] Miller A, Shapiro S, Gershtein R, Kinarty A, Rawashdeh H, Honigman S, et al. Treatment of multiple sclerosis with copolymer-1 (Copaxone): implicating mechanisms of Th1 to Th2/Th3 immune deviation. J Neuroimmunol 1998;92:113-21.

[270] Rudick RA, Ransahoff RM, Lee JC, Peppler R, Yu M, Mathisen PM, et al. In vivo effects of interferon beta-1a on immunosuppressive cytokines in multiple sclerosis. Neurology 1998:50:1294-300.

[271] Bartosik-Psujek H, Stelmasiak Z. Interleukin-10 levels as potential indicator of positive response to interferon beta treatment of multiple sclerosis patients. Clin Neurol Neurosurg 2006;108:644-7.

[272] Graber JJ, Ford D, Zhan M, Francis G, Panitch H, Dhib-Jalbut S. Cytokine changes during interferon-beta therapy in multiple sclerosis: correlations with interferon dose and MRI response. J Neuroimmunol 2007;185:168-74.

[273] Sheremata WA, Jy W, Delgado S, Minagar A, McLarty J, Ahn Y. Interferon-beta1a reduces plasma $\mathrm{CD} 31^{+}$endothelial microparticles $\left(\mathrm{CD} 31^{+} \mathrm{EMP}\right)$ in multiple sclerosis. J Neuroinflammation 2006;3:23

[274] Lowery-Nordberg M, Eaton E, Gonzalez-Toledo E, Harris MK, Chalamidas K, McGee-Brown J, et al. The effects of high dose interferon- $\beta 1$ a on plasma microparticles: correlation with MRI parameters. J Neuroinflammation 2011;8:43.

[275] Kemppinen AK, Kaprio J, Palotie A, Saarela J. Systematic review of genome-wide expression studies in multiple sclerosis. BMJ Open 2011;1:e000053.

[276] Comabella M, Martin R. Genomics in multiple sclerosis - current state and future directions. J Neuroimmunol 2007;187:1-8.

[277] Weinstock-Guttman B, Bhasi K, Badgett D, Tamanõ-Blanco M, Minhas M, Feichter J, et al. Genomic effects of once-weekly, intramuscular interferon-beta1a treatment after the first dose and on chronic dosing: relationships to 5-year clinical outcomes in multiple sclerosis patients. J Neuroimmunol 2008;205:113-25.

[278] Hecker M, Goertsches RH, Fatum C, Koczan D, Thiesen HJ, Guthke R, et al Network analysis of transcriptional regulation in response to intramuscular interferon- $\beta-1 a$ multiple sclerosis treatment. Pharmacogenomics J 2012;12:134-46.

[279] O'Connell RM, Rao DS, Chaudhuri AA, Baltimore D. Physiological and pathological roles for microRNAs in the immune system. Nat Rev Immunol 2010;10:111-22.

[280] Hecker M, Thamilarasan M, Koczan D, Schroder I, Flechtner K, Freiesleben S, et al. MicroRNA expression changes during interferon-beta treatment in the peripheral blood of multiple sclerosis patients. Int J Mol Sci 2013;14:16087-110.

[281] Waschbisch A, Atiya M, Linker RA, Potapov S, Schwab S, Derfuss T. Glatiramer acetate treatment normalizes deregulated microRNA expression in relapsing remitting multiple sclerosis. PLoS One 2011;6:e24604

[282] Huang B, Zhao J, Lei Z, Shen S, Li D, Shen GX, et al. miR-142-3p restricts cAMP production in $\mathrm{CD} 4^{+} \mathrm{CD} 25^{-}$T cells and $\mathrm{CD} 4^{+} \mathrm{CD} 25^{+}$Treg cells by targeting AC9 mRNA. EMBO Rep 2009;10:180-5.

[283] O'Connell RM, Kahn D, Gibson WS, Round JL, Scholz RL, Chaudhuri AA, et al. MicroRNA-155 promotes autoimmune inflammation by enhancing inflammatory T cell development. Immunity 2010;33:607-19.

[284] Sievers C, Meira M, Hoffmann F, Fontoura P, Kappos L, Lindberg RL. Altered microRNA expression in B lymphocytes in multiple sclerosis: towards a better understanding of treatment effects. Clin Immunol 2012;144:70-9.

[285] Engelhardt B, Kappos L. Natalizumab: targeting alpha4-integrins in multiple sclerosis. Neurodegener Dis 2008:5:16-22.

[286] Yousry TA, Major EO, Ryschkewitsch C, Fahle G, Fischer S, Hou J, et al. Evaluation of patients treated with natalizumab for progressive multifocal leukoencephalopathy N Engl J Med 2006;354:924-33.

[287] Bloomgren G, Richman S, Hotermans C, Subramanyam M, Goelz S, Natarajan A et al. Risk of natalizumab-associated progressive multifocal leukoencephalopathy. N Engl J Med 2012;366:1870-80.

[288] Carson KR, Focosi D, Major EO, Petrini M, Richey EA, West DP et al Monoclonal antibody-associated progressive multifocal leucoencephalopathy in patients treated with rituximab, natalizumab, and efalizumab: a review from the Research on Adverse Drug Events and Reports (RADAR) Project. Lancet Oncol 2009;10:816-24.

[289] Major EO. Progressive multifocal leukoencephalopathy in patients on immunomodulatory therapies. Annu Rev Med 2010;61:35-47.

[290] Lin J, Bettin P, Lee JK, Ho JK, Sadiq SAJ. Cerebrospinal fluid and serum JC virus antibody detection in multiple sclerosis patients treated with natalizumab. Neuroimmunol 2013;261:123-8

[291] Clifford DB, De Luca A, Simpson DM, Arendt G, Giovannoni G, Nath A. Natalizumabassociated progressive multifocal leukoencephalopathy in patients with multiple sclerosis: lessons from 28 cases. Lancet Neurol 2010;9:438-46.

[292] Laroni A, Giacomazzi CG, Grimaldi L, Gallo P, Sormani MP, Bertolotto A, et al Urinary JCV-DNA testing during natalizumab treatment may increase accuracy of PML risk stratification. J Neuroimmune Pharmacol 2007;7:665-72.

[293] Trampe AK, Hemmelmann C, Stroet A, Haghikia A, Hellwig K, Wiendl H, et al. Anti$\mathrm{JC}$ virus antibodies in a large German natalizumab-treated multiple sclerosis cohort. Neurology 2012;78:1736-42. 